NBER WORKING PAPER SERIES

\title{
DOES INWARD FOREIGN DIRECT INVESTMENT BOOST THE PRODUCTIVITY OF DOMESTIC FIRMS?
}

\author{
Jonathan E. Haskel \\ Sonia C. Pereira \\ Matthew J. Slaughter \\ Working Paper 8724 \\ http://www.nber.org/papers/w8724 \\ NATIONAL BUREAU OF ECONOMIC RESEARCH \\ 1050 Massachusetts Avenue \\ Cambridge, MA 02138 \\ January 2002
}

For very helpful discussion we thank Andrew Bernard, Bruce Blonigen, Steve Machin, Nina Pavcnik, Dave Richardson, Joel Slemrod, Scott Stern, and seminar participants at London School of Economics, University of Michigan, Syracuse University, the CEPR Labor Economics Workshop, and the NBER Summer Institutes for Productivity and International Trade and Investment. The data in this paper were used as part of the U.K. Office of National Statistics business-data-linking project. For financial support Haskel and Pereira thank the U.K. Economic and Social Research Council for grant \#R000223239, and Slaughter thanks the National Science Foundation and the National Bureau of Economic Research. The views expressed herein are those of the authors and not necessarily those of the National Bureau of Economic Research.

(C) 2002 by Jonathan E. Haskel, Sonia C. Pereira and Matthew J. Slaughter. All rights reserved. Short sections of text, not to exceed two paragraphs, may be quoted without explicit permission provided that full credit, including $\odot$ notice, is given to the source. 
Does Inward Foreign Direct Investment Boost the Productivity of Domestic Firms?

Jonathan E. Haskel, Sonia C. Pereira and Matthew J. Slaughter

NBER Working Paper No. 8724

January 2002

JEL No. F2, L1

\begin{abstract}
Are there productivity spillovers from FDI to domestic firms, and, if so, how much should host countries be willing to pay to attract FDI? To examine these questions we use a plant-level panel covering U.K. manufacturing from 1973 through 1992. Across a wide range of specifications, we estimate a significantly positive correlation between a domestic plant's TFP and the foreign-affiliate share of activity in that plant's industry. This is consistent with positive FDI spillovers. We do not generally find significant effects on plant TFP of the foreign-affiliate share of activity in that plant's region. Typical estimates suggest that a 10 percentage-point increase in foreign presence in a U.K. industry raises the TFP of that industry's domestic plants by about 0.5 percent. We also use these estimates to calculate the perjob value of these spillovers. These calculated values appear to be less than per-job incentives governments have granted in recent high-profile cases, in some cases several times less.
\end{abstract}

Jonathan E. Haskel

Department of Economics

Queen Mary College

University of London

London E1 4NS

England

and CEPR

j.e.haskel@qmw.ac.uk
Sonia C. Pereira

Department of Economics

Queen Mary College

University of London

London E1 4NS

England

s.pereira@qmw.ac.uk
Matthew J. Slaughter

Department of Economics

Dartmouth College

309 Rockefeller Hall

Hanover, NH 03755

and NBER

slaughter@dartmouth.edu 


\section{Introduction}

An important part of globalization in recent years has been the ongoing rise in foreign direct investment (FDI). UNCTAD (2000) reports that from 1979 to 1999, the ratio of world FDI stock to world gross domestic product rose from $5 \%$ to $16 \%$ and the ratio of world FDI inflows to global gross domestic capital formation rose from $2 \%$ to $14 \%$. One consequence is that an increasing share of countries' output is accounted for by foreign affiliates of multinational firms. The foreign-affiliate share of world production is now $15 \%$ in manufacturing and other tradables (Lipsey, et al, 1998).

An obvious policy issue for governments is whether incentives should be offered to multinational firms to induce local affiliate production. In recent decades dozens of countries have altered laws to at least grant multinationals national treatment, if not to favour these firms via policies such as subsidies and tax breaks (UNCTAD, 2000). ${ }^{1}$ Policy promotion of FDI is now common not just in developing countries but in many developed countries as well. The exact values of FDI incentive packages are typically hard to know, but the values of many wellknown FDI packages appear very high. In the late 1980s the U.S. state of Kentucky offered Toyota an incentive package worth (in present value) \$125-\$147 million for a plant planning to employ 3,000 workers (Black and Hoyt, 1989). In 1994 the state of Alabama offered Mercedes an incentive package of approximately \$230 million for a new plant planning to employ 1,500 workers (Head, 1998). In 1991 Motorola was paid $£ 50.75$ million to locate a mobile-phone plant in Scotland, employing 3,000 workers. The factory closed in 2001, and Motorola paid back $£ 16.75$ million in grants. Siemens was offered $£ 50$ million in 1996 to locate a 1000 -worker semiconductor plant in Tyneside, in Northeast England. The factory closed 18 months later, at which point Siemens had to repay $£ 18$ million in grants.

Is there economic justification for this kind of policy promotion? There would be if the social returns to FDI exceed the private returns. One often-claimed possibility is that inward FDI raises the productivity of domestic plants by bringing new knowledge into the host country that is, at least partly, a public good. This positive externality of knowledge spillovers may arise along industry and/or regional lines.

\footnotetext{
${ }^{1}$ For example, as Aitken and Harrison (1998) document, before 1989 foreign firms in Venezuela were taxed at a higher rate than domestic firms $(50 \%$ versus $35 \%)$, were forced to repatriate profits at officially fixed exchange rates and could not enjoy confidentiality privileges in joint ventures. See Hanson (2001) for an overview of issues involved in FDI policy.
} 
There are thus two empirical questions that we seek to shed light on in this paper. First, are there productivity spillovers from FDI to domestic firms? Second, if so, how much should host countries be willing to pay to attract FDI? Despite the public interest and policy importance of these two questions, there is very little empirical evidence offering answers.

Existing evidence on whether there are productivity spillovers is of three types. The first are case studies. Cases can offer rich description about episodes and exemplify general issues, but do not always offer quantitative information and do not easily generalize. Second, there are industry-level studies (e.g., Caves, 1974; Blomstrom, 1986; and Driffield, 2000). Many have documented a positive industry-level correlation between FDI inflows and productivity. However, the causal meaning of this correlation is unclear. It may be that inward FDI raises host-country productivity via spillovers. But it may also be that inward FDI raises host-country productivity by forcing the exit of low-productivity domestic plants, or simply by raising the market share of foreign firms who are, on average, more productive. Or it may be that multinationals tend to concentrate in high-productivity industries. This latter interpretation is consistent with recent "knowledge-capital" models of multinational firms, in which these firms generate knowledge assets that can be deployed in different countries (e.g., Carr, et al, 2001).

The third set of studies are micro-level analyses. These studies examine whether the productivity of domestic plants (or firms) is correlated with FDI presence in the industry and/or region of the domestic plants. Of the few micro-level studies we are aware of, only one finds any evidence of positive spillovers. Haddad and Harrison (1993) find increased industry-level FDI is correlated with lower domestic-plant productivity in Moroccan manufacturing plants. Aitken and Harrison (1999) find the same negative result for Venezuelan manufacturing. They suggest these negative spillovers reflect adverse effects of FDI due to competition and further that FDI spillovers might not be positive in developing countries whose firms do not have the absorptive capacity. Chung, et al (1998) find that Japanese automobile firms operating in the United States did not boost the productivity of their American component-supplier firms via technology spillovers. Girma and Wakelin (2001) look at one industry, U.K. electronics, and find a positive correlation between domestic-firm productivity and regional Japanese FDI.

\footnotetext{
${ }^{2}$ Using data not on firms or plants but rather data on patent citations, Branstetter (2001) looks for spillovers of Japanese FDI into the United States. Subsequent to our work in this paper, Harris and Robinson (2001) look for spillovers in a collection of 20 detailed U.K. industries. In footnote 21 we compare our methods with theirs.
} 
To bring some fresh evidence to bear on this issue, we use a plant-level panel for all U.K. manufacturing from 1973 through 1992, where each plant reports information on nationality of ownership. Our main innovation is that we are, to the best of our knowledge, the first paper to study FDI spillovers using plant-level data spanning the entire manufacturing sector of a developed country. The U.K. is of interest for a number of reasons. First, by virtue of being a high-income country that is among the top-five R\&D producers in the world (Keller, 2001), there is ex ante reason to suppose that it has sufficient absorptive capacity to realize FDI spillovers. Second, in recent decades the U.K. has seen substantial inflows of FDI. In our panel the foreignaffiliate share of manufacturing employment has risen from $12 \%$ in 1973 to $23 \%$ in 1992. Third, in recent years the U.K. government has spent hundreds of millions of pounds in incentives for foreign firms both to locate in the U.K. and to expand existing U.K. production. With estimates of spillovers, we can undertake some simple calculations to evaluate these actual government outlays.

We study whether domestically owned plants are more productive when foreign-owned plants are present. Our general approach will be to regress domestic plant-level output on domestic plant-level inputs, measures of foreign presence in the plant's industry and region, and other control regressors. We interpret coefficient estimates on our FDI regressors as evidence consistent with spillovers from inward FDI to domestic-plant total-factor productivity (TFP). As we will discuss, this rich data set raises a number of estimation issues regarding endogeneity, measurement, and selection. We will exploit the panel nature of our data in various ways to try to address these issues and thereby gauge the robustness of our results. In addition, we will examine if FDI spillovers vary across dimensions including absorptive capacity of domestic plants and nationality of foreign investors.

Our main finding is evidence consistent with FDI spillovers along industry lines. Across a wide range of specifications, on our full sample we estimate a significantly positive correlation between a domestic plant's TFP and the foreign-affiliate share of activity in that plant's industry. Typical estimates suggest that a 10 percentage-point increase in foreign presence in a U.K. industry raises the TFP of that industry's domestic plants by about 0.5 percent. We estimate this

\footnotetext{
${ }^{3}$ The Appendix describes how the U.K. government subsidizes inward FDI. In general, the government offers incentives to many types of foreign-affiliate activity deemed worthy, where employment protection/expansion is a prominent criterion. Between 1985 and 1988, 58\% of Regional Selective Assistance (RSA, the major source of U.K. government support for firms) went to plant expansions and $25 \%$ to new plants, and foreign firms received $60 \%$ of the value of RSA (PA Consultants, 1993, Tables 2.3 and11.1, respectively).
} 
TFP/foreign-affiliate correlation to be stronger for plants that are smaller, less technologically advanced, and less skill intensive, suggesting that spillovers accrue predominantly to "lagging" domestic plants, not "leading" ones. We also find this correlation to be stronger for U.S. and French FDI, suggesting different spillover potentials for different parent countries. We find no significant correlation between plant TFP and FDI presence by region.

We then use our typical estimates of FDI spillovers to calculate the amount by which an additional foreign job in a U.K. industry boosts the output of domestic plants in that industry. This amount is about $£ 2000$ per year at 1992 prices. We then compare these spillover benefits with the per-job incentives governments have granted in several recent high-profile cases. The spillover magnitudes appear to be less than actual per-job incentives, in some cases several times less. This suggests that productivity spillovers alone might not justify some of the recent highprofile policy initiatives.

There are five sections to the rest of the paper. Section 2 briefly discusses the theory of productivity spillovers. Section 3 discusses our data, measurement, and estimation issues. Section 4 presents our empirical findings, and Section 5 discusses their public-finance implications. Section 6 concludes. 7

\section{Multinationals and Theories of Productivity Spillovers}

Many standard models of multinational firms assume they possess knowledge assets (e.g., patents, proprietary technology, trademarks, etc.) that can be deployed in plants outside the parent country. This knowledge aspect of multinationals is a key feature of recent generalequilibrium models such as Carr, et al (2001) and earlier work such as Dunning's (1981) "OLI" framework, in which a necessary condition for a firm to become multinational is that it possess an "ownership advantage" over some mobile knowledge asset. This knowledge-asset view is supported empirically. For example, multinationals are much more R\&D-intensive than are purely domestic firms (e.g., Griffiths, 1999).

If multinationals transfer knowledge from parents to their foreign affiliates, then it is possible that some of this knowledge "spills over" to domestic firms in the host country through non-

\footnotetext{
${ }^{4}$ Beyond knowledge spillovers, foreign presence may raise aggregate U.K. productivity by inducing exit of domestic firms and/or by exerting competitive pressure on domestic firms. Our focus on knowledge spillovers is for surviving domestic plants, but we consider foreign presence when addressing selection issues. We also try to control for competitive pressures. Relatedly, our analysis is only for domestic plants, and does not address the relative performance of foreign and domestic plants (e.g., Griffith, 1999; Oulton, 2000; Harris, 2001).
} 
market transactions. The general idea that interaction among firms can generate spillovers dates back to at least Marshall (1920). Mansfield and Romeo (1980) present survey evidence in which U.S. multinationals reported the frequency and pace at which their technology deployed in foreign affiliates reached host-country competitors, all evidence consistent with multinational spillovers.

Theoretical work on the mechanics of spillovers ranges from general discussions, often leavened with anecdotes, to formal general-equilibrium models. Broadly speaking, spillovers are commonly hypothesized to fall along industry or regional lines. An example of multinational spillovers along industry lines is Rodriguez-Clare (1996), in which affiliates increase a host country's access to specialised varieties of intermediate inputs, the improved knowledge of which raises the TFP of domestic producers. Less formally, it is often hypothesized that domestic firms learn from affiliates in the same industry via a range of informal contacts (e.g., trade shows; supplier/distributor discussions; exposure to affiliate products, marketing, and patents; technical support from affiliates; reverse engineering).

Other spillover mechanisms may operate along regional lines. One commonly proposed avenue (since at least Marshall, 1920) is via labor turnover. If at least some of the knowledge particular to foreign affiliates is embodied in their labor force, then as affiliate employees leave to work for domestic firms this knowledge may move as well. For example, Song, et al (2001) use U.S. patent records to trace the movement of scientists between domestic and foreign firms (also see Motta, et al, 1999, and Moen, 2000). This knowledge need not be firm-specific (e.g., inventory-control or management techniques). If inter-regional labor mobility within a country is low, then these spillovers are likely to be concentrated within regions where the affiliates operate rather than dispersed country-wide. More generally, regional labor-market spillovers can be thought of as one important kind of agglomeration economy that can induce firms to locate near each other in space. Krugman (1991) offers some formal models of agglomeration issues.

Overall, then, there is reason to suppose that inward FDI may boost the productivity of domestic plants either along industry lines or along regional lines. Accordingly, we plan to investigate both empirically by looking for a correlation between domestic-plant productivity 
and industry and regional measures of foreign-plant presence. Such a correlation we will interpret as evidence consistent with the presence of productivity spillovers.

\section{Data, Measurement, and Econometrics}

\section{3a. Overview of the ARD Data Set}

Details of our data can be found in Griffith (1999), Oulton (1997), Disney, et al (2000), and the Data Appendix. Here we briefly set out the main features of the data, and concentrate on issues involved in calculating productivity and foreign presence.

Our main data set is the ARD (Annual Census of Production Respondents Database), which is the micro-data underlying the U.K. Census of Production. The basic unit on the ARD is a production facility at a single mailing address, which corresponds to a "production unit" or "plant." Each unit is assigned a unique identification number, which allows units to be linked over time into a panel. Units also have another identification number corresponding to the firm who owns them, where units under common ownership share the same firm identifier.

To maintain the ARD data, the Office for National Statistics (or ONS, previously the Central Statistical Office, or CSO) maintains a register of businesses designed to capture the universe of production-sector activity. The register is drawn from a variety of sources including historical records, tax returns and other surveys. ${ }^{6}$ This register is the basis upon which the Census forms are sent out, response to which is mandatory under the 1947 Statistics of Trade Act. These forms request extensive operational information on inputs and outputs, which as discussed below we use to estimate productivity. Crucially for our purposes, the ONS also collects information on plants' industry, region, and nationality of ownership.

In at least two ways, the U.K. government has reduced the reporting burden on firms. First, it has not required all smaller plants to fill out Census forms. Each year, all plants with employment over some minimum size (100 in most years) are sampled. Plants with employment below this threshold are sampled with probabilities decreasing in size: in most years, $50 \%$ of plants with employment from 50 to 100 are sampled, and $25 \%$ of plants with employment from

\footnotetext{
${ }^{5}$ If multinational firms are aware of their ability to generate spillovers, then their operational decisions may be endogenous to this possibility-e.g., they may attempt to minimize spillovers' benefits to competitors. Evidence consistent with this appears in Mansfield and Romeo (1980), where the age of technology transferred to affiliates varies with mode of foreign entry, and in Shaver and Flyer (2000), where larger foreign firms are found to be less likely to build U.S. plants near other competitors. See our discussion below for our treatment of endogeneity; other discussion of these issues appears in Kugler (2001).

${ }^{6}$ Thus, for example, the 1983 Value Added Tax Act allowed the CSO to start using VAT information in compiling the register. In 1994, the CSO moved to a completely new register. See Perry (1985) for details on the ARD's sampling methods.
} 
20 to 50. The very smallest plants each year are excluded from the Census. Thus, each year's sample consists of a mix of larger plants sampled with certainty and smaller plants sampled with varying probabilities. The sampled plants altogether are referred to as the "selected sample," while all non-sampled plants constitute the "non-selected sample." Each year the selected sample accounts for around 90\% of total U.K. manufacturing employment (Oulton, 1997).

A second reporting-burden issue is that multi-plant firms have some latitude in the level of aggregation at which they report plant information. If a multi-plant firm considers some of its individual plants to be too small to complete a full Census form, it may report an amalgamation of plants. This reporting level is called an "establishment."

Computerized ARD records go back to 1972; paper records for earlier years have been destroyed. In 1993 and 1994, a complete recoding of identification numbers was undertaken that has generated non-trivial problems in matching plants before and after. Thus, our data run through 1992, a period which fortunately covered a substantial increase in FDI inflows.

The ARD structure raises many issues for our data analysis. Here we highlight two, with these and additional issues-e.g., sample selection-addressed more in the next sub-section. First is the level of aggregation at which to investigate productivity spillovers. In principle, the ARD panel can be configured for plants, establishments, or firms. However, at the level of firms, spillovers might be obscured for multi-plant firms in multiple regions and/or industries. And since multi-plant firms that aggregate operations into establishments do not report data for each separate plant, at the level of plants we cannot measure TFP for all observations. Accordingly, we choose to work at the level of establishments, which is the most-disaggregated level at which we can measure TFP. For brevity, we will use the terms establishments and plants interchangeably. That said, it is important to remember that because of firms' reporting latitude, ARD establishments can consist of more than one plant. We will check the robustness of our estimation results to this.

A second issue is what information, if any, can be used from the non-selected data. Since these businesses are not sent a full Census form, we have no information on their inputs (such as material and investment). They do report on nationality of ownership. The ONS imputes their employment levels using turnover data from tax records. The ONS does check employment for plants with imputed employment of over 11. However, due to time lags in the provision of tax data and processing of imputations, such information is typically refers to data from two years 
earlier (Perry, 1985). In addition, these checked plants are only around $20 \%$ of the non-selected sample. In sum, we cannot use the non-selected data for productivity calculations. But we could potentially use the employment data to measure foreign presence and/or to weight the selected sample. We address both these issues below.

Finally, before our analysis we cleaned the data via extensive checks for nonsense observations, outliers, coding mistakes, and the like. This task is important in itself, but takes on additional significance for any analysis on time-differenced data, as differencing tends to magnify the role of measurement error. For example, plant identification numbers are supposed to die with the plant, so we deleted any observations where plant identifiers returned after dropping out of the entire data set. ${ }^{\square}$ We dropped publicly owned plants (mainly in utilities), and plants that seemed to change ownership, industry, or region in unusual fashion. Finally, when running regressions we deleted plants in the top and bottom percentiles of changes in all plantspecific output and input variables.

\section{3b. Specification, Measurement, and Estimation Issues}

\section{Specification}

To investigate whether inward FDI generates productivity spillovers for domestic plants, we estimate variations of the following basic equation specification.

$$
\ln Y^{d}{ }_{i t}=\alpha \ln I N P U T^{d}{ }_{i t}+\sum_{k=0}^{T} \gamma_{1}^{k} F O R_{R, t-k}+\sum_{k=0}^{T} \gamma_{2}^{k} F O R_{I, t-k}+\delta Z^{d}{ }_{i t}+\varepsilon_{i t}
$$

In (1), subscripts $i, t, k, R$ and $I$ denote plant, time, lag length, region, and industry; $\alpha, \gamma$, and $\delta$ are parameters to be estimated; and the superscript $d$ denotes that plants are domestically owned. Output of domestic plants is denoted $Y^{d}$, their inputs denoted INPUT ${ }^{d}$, foreign presence in the region and industry $F O R_{R}$ and $F O R_{I}, Z^{d}$ are other control regressors, and $\varepsilon$ is an unobserved influence on domestic plant productivity. Thus (1) is a production function for domestic plants, augmented by measures of foreign presence and other controls, where coefficient estimates on the non-input regressors capture their contribution to TFP. As written in (1), these estimates are the same across all panel dimensions; in our robustness checks we relax this in various ways.

\footnotetext{
${ }^{7}$ A plant might truly do this if it happens not to be sampled for full Census information for some period because of its small size, but we can check on this using the plant records for those who do not fill out the full Census form.
} 
An alternative strategy to (1) would be to calculate TFP using data on outputs, inputs, and input-cost shares, and then regress calculated TFP on the non-input regressors in (1). In our robustness checks we report results from this alternative.

As in all micro-level empirical work with production functions, we face important concerns involving measurement and also estimation. We discuss each of these issues in turn, with additional measurement discussion in the Data Appendix.

\section{Measurement}

Output is measured as gross output. For INPUT we use capital, $K$; production and nonproduction labour, $L^{U}$ and $L^{S}$ (for unskilled and skilled); materials, $M$; and hours, $h . L^{U}, L^{S}$ and $M$ are available directly from the Census full-form surveys. $L^{U}$ and $L^{S}$ count employment of both part-time and full-time workers, and $M$ measures the value of both energy and non-energy materials purchases. Hours are available only at the two-digit industry level. Output and materials are deflated using industry-level price indexes as detailed as possible. ${ }^{0}$ The ARD does not ask plants to report capital stocks, so we used plant investment data to calculate capital stocks. We chose industry-level starting capital-stock values and depreciation rates for buildings, plant and machinery, and vehicles taken from O'Mahony and Oulton (1990). We deflated each component of investment by ONS industry-year investment deflators. We experimented with different capital-stock computations (the two main variables affecting the capital-stock path are starting values and depreciation rates), but these did not overly affect the results.

The $F O R_{R}$ and $F O R_{I}$ terms in equation (1) are foreign presence by region and by industry. Nationality of plant ownership is defined according to whether an overseas investor has an effective voice in the management of the enterprise, where an effective voice is taken as equivalent to a holding of $20 \%$ or more in the foreign enterprise. In our data, then, foreignaffiliate plants are those plants owned at least $20 \%$ by an overseas business interest. Note that beyond this $20 \%$ cut-off, the ARD does not measure the degree of foreign ownership. Also note that domestic plants mix both U.K.-headquartered multinational firms and purely domestic U.K. plants, as the ARD does not provide any ownership distinction among domestically owned

\footnotetext{
${ }^{8}$ See Bartelsman and Doms (2000) for a detailed discussion of data issues specific to micro-level data sets.

${ }^{9}$ Our lack of plant-level prices is a pervasive problem in the literature on micro panels. To preview our interest in the correlation between foreign presence and productivity, if inward FDI lowers industry prices then there may be a spurious correlation between foreign presence and our measure of plant productivity. Without plant-level prices we cannot assess the importance of this effect. But if it were important, then all plant-level studies should automatically find this correlation.
} 
plants. Despite these caveats, one important advantage of the ARD over similar data sets for most other countries is that it reports nationality of ownership in every year. 10

Given this information on nationality of ownership, we measure $F O R_{R}$ as the share of total employment in region $R$ accounted for by foreign-owned plants. $F O R_{I}$ is constructed analogously, as the share of total employment in industry $I$ accounted for by foreign-owned plants. There are several points to make regarding measurement of these important variables.

First, these shares capture the idea that what matters for spillovers is how prevalent foreigners are in the domestic region or industry, scaling for the overall size of that industry or region. Other micro-level spillover studies have used share measures of foreign presence. 11 To examine the separate role of each share's two components, total foreign employment and total employment, we also estimate specifications that decompose the shares.

Second, to construct the shares we prefer employment as the activity measure because many spillover theories (Section 2) involve interpersonal contacts. One obvious alternative is to use capital, the other primary factor. Another possibility is employment of a particular skill group. More-skilled non-production workers might embody most of the spillovers, e.g., due to their greater knowledge of technology innovations. Or production workers might be those most familiar with specific production techniques (e.g., leaner assembly-line operations) that boost productivity. Below, we report results for these alternatives.

Third, our baseline specifications measure $F O R_{R}$ and $F O R_{I}$ using plants in the ARD's selected sample. As discussed in subsection 3a, we can also measure these shares using both the selected and non-selected samples. The trade-off is comprehensiveness against data quality. The non-selected sample does cover around $10 \%$ of total U.K. manufacturing employment. But $80 \%$ of the non-selected employment data are imputed, not reported, and thus introduce greater measurement error into $F O R_{R}$ and $F O R_{I}$. Concern about this measurement error leads us to use just the selected sample as our baseline. In our robustness checks we report the alternative of

\footnotetext{
${ }^{10}$ In contrast, the widely used analogous U.S. data base, the Longitudinal Research Database, does not track nationality of ownership. The only year in which nationality information was merged in (from the U.S. Bureau of Economic Analysis) was 1987 (see examination of this one year in Doms and Jensen, 1998). For the countries providing information and data to the current OECD micro-data project (Finland, Holland, France, U.S., U.K., Germany and Italy), nationality of ownership data is missing for Germany, Holland, Italy, and the U.S.; the French data are incomplete; and only the U.K. and Finland have such data. ${ }^{11}$ Different papers have used slightly different specifications of foreign presence, though. For example, Aitken and Harrison (1999) use $F O R_{I}$ and also the interaction of foreign ownership in the same industry and region. One advantage of separating our foreign-presence measures by industry and region is that if spillovers along these different dimensions take different times, then our separated terms can be entered with different lag lengths. We tried various specifications with interacted measures, but these were consistently insignificant.
} 
measuring foreign presence using employment from both the selected and non-selected samples. Using the non-selected data also raises the estimation issue of weighting observations, as the ARD is a size-based sample. We address this below.

Fourth, as indicated in equation (1) we allow these foreign-presence measures to enter both contemporaneously and with lags. This is because although theory suggests that FDI spillovers may take time to arise (e.g., labor turnover to domestic plants), there is not sharp empirical evidence on this issue as to exactly how long. Our specifications will try many lag structures. 12

Fifth, theory offers no sharp prediction as to how narrowly or broadly regions and industries should be measured. We distinguish 11 different U.K. regions. These are commonly used regions originally identified in the U.K. censuses of population, and they fall across conventional political and other boundaries. For $F O R_{I}$ we distinguish 22 different manufacturing industries; these are roughly comparable to two-digit Standard Industrial Classification industries for U.S. manufacturing. There was a major revision to the U.K. industry classifications in 1980 . These reclassifications make it difficult to separate industries in greater detail with confidence, so to minimize potential measurement error our baseline is to use the 22 two-digit industries. This practical issue aside, there may be reason to think industry-mediated spillovers are not "too narrow". For example, inventory-management techniques in apparel production might apply to a wide range of apparel goods_-men's, women's, and children's. Or, as discussed in Section 2, spillovers may arise from supplier and/or customer interactions-e.g., windshield producers learning from automobile firms.

Table 1 reports some basic ownership information in our ARD panel. As column 1 shows, we have usable data on 13,000-23,000 plants per year. Columns 2 and 3 show the bulk of those are British owned, but column 4 shows that the fraction of manufacturing employment accounted for by foreign affiliates grew from $12 \%$ in 1973 to $23 \%$ in 1992 . The general decline in the number of British plants in Table 1 is consistent with the general decline during our sample period in overall U.K. manufacturing activity. ${ }^{13}$ Note that given how we construct $F O R_{R}$ and $F O R_{I}$, this decline will tend to increase our foreign-presence measures even if there is no change

\footnotetext{
12 In Mansfield and Romeo's (1980) surveys, U.S. multinationals report that their technology deployed in foreign affiliates reached host-country competitors in anywhere from zero to over 6.5 years, with a modal response of 0.5 to 1.5 years and a mean response of about four years.

${ }^{13}$ Office of National Statistics (1998) reports that total U.K. manufacturing employment fell from 6.446 million in 1980 to 4.084 million in 1992. There is a spike in the number of plants in 1984 and 1989 because the Central Statistical Office changed the compilation method of the register (see Disney, et al, 2000).
} 
in FDI activity. To control for this, we will estimate specifications that add to equation (1) the lagged number of British plants by region and industry. Entering separately the numerators and denominators of $F O R_{R}$ and $F O R_{I}$ will also control for this.

Tables $2 \mathrm{a}$ and $2 \mathrm{~b}$ show the regional and industrial variation, respectively, in foreignemployment shares for 1977 and 1992. By region, foreign presence was highest in the South East in the 1970s, but by 1992 Wales was the highest. By industry, foreign presence was generally highest in office machinery, motor vehicles, and chemicals. But the ranking of foreign presence in regions and industries is not fixed, and the panel nature of our data allows us to exploit this variation.

Turning to the control regressors $Z$ in equation (1), one important set of controls is for product-market competition. There is now a large literature suggesting that competition affects the productive efficiency (i.e., X-inefficiency) of firms (for a theory review see Vickers, 1995; for empirical evidence see Nickell, 1996). The idea that foreign competition through FDI can exert competitive pressures has been both discussed and empirically analyzed in many studies (e.g., Caves, 1974; Blomstrom, 1986; Chung, et al, 1998). More generally, Baily and Solow (2001) survey a wide range of micro evidence that international competition of many formsincluding both FDI and trade-spurs competitive responses in exposed firms.

It seems reasonable that the entry of foreign firms might raise the degree of competition and hence the effort level that domestic firms must exert to remain viable. This pro-competitive effect might be regarded as a spillover effect, but the welfare consequences of this are different from the knowledge spillovers that theory tends to focus on. Knowledge spillovers are Paretoimproving positive externalities, whereas increased effort represents a welfare transfer away from the harder-working employees to shareholders and/or customers. Hours is our only possible effort measure thus far, so without direct controls for competition the coefficient on $F O R_{I}$ might reflect both knowledge spillovers and the effects of competition. Indeed, Aitken and Harrison (1999) ascribe their finding of negative spillovers to competition: foreign entrants take domestic firms' market shares, and thereby force domestic incumbents up their average-cost curves. All this suggests the need to control for product-market competition.

\footnotetext{
${ }^{14}$ Note that including inputs in equation (1) should help control for the output consequences of plants moving along their average-cost curves. Also, it seems unlikely that manufacturing plants compete along regional lines. This suggests that the coefficients on $F O R_{R}$ are unlikely to reflect increased effort.
} 
Following Nickell (1996), we use four potential measures of product-market competition: industry concentration $\left(C O N C_{I t}\right)$, import penetration $\left(I M P O R T_{I t}\right)$, market share $\left(M S H A R E_{i t}\right)$ and rents $\left(\operatorname{RENTS}_{i t}\right)$. IMPORT is available at the industry-level as imports as a share of domestic production. MSHARE is measured as plant output as a proportion of four-digit-industry output. This is unlikely to be a reliable cross-section measure of market power, since it is affected by technological differences between industries (e.g., capital intensity) which also likely affect productivity. Accordingly, we use changes in market share, $\triangle M S H A R E$, to measure changes in competitive pressure. RENTS aims to capture ex ante rents potentially available to workers and managers to take as increased leisure. It is defined as sales less material, capital and labour costs, expressed as a proportion of net output (where we measure labor cost using industryregion average wages instead of actual plant wages).

\section{Estimation Issues}

One important estimation issue is endogeneity. This is a particular concern for our key regressors of interest, $F O R_{R}$ and $F O R_{I}$. Foreign firms may be attracted to regions and/or industries with high-productivity domestic plants-e.g., perhaps learning spillovers flow in both directions. To address this possibility, we use lagged measures of $F O R_{R}$ and $F O R_{I}$. Above, we argued that lags may be appropriate because spillovers take time to materialize. Lagged foreign presence is also predetermined relative to current plant productivities. We also suspect that the competition regressors may be endogenous: e.g., higher plant efficiency might raise rents and market share. We therefore lag RENTS and $\triangle M S H A R E$ by two years. 6

A second estimation issue is omission of unobserved variables. There are likely to be a host of plant, industry, time, and region-specific influences that are unobservable to the econometrician but are known to the plant. These unobservables might underlie any observed correlation between productivity and foreign presence. For example, sound infrastructure or high-quality management might both raise domestic productivity and attract foreign firms.

We attempt to address this omitted-variables problem via time differencing and fixed effects. First, we estimate (1) on time-differenced data. In addition to removing any fixed plant-specific

\footnotetext{
${ }^{15}$ We also calculated market shares for three- and two-digit industries. The coefficient standard error rose as we did this, suggesting that the measure becomes increasingly inaccurate as we use a broader base, which is plausible.

${ }^{16}$ The other obvious option would be to instrument for foreign presence, using some variable correlated with foreign presence but uncorrelated with unobservable determinants of plant productivity. In our data we know of no good candidates. Government policies (and changes therein) are one common candidate set of instruments. We do have data since 1980 on U.K. government support for firms by region, but this support was available for all firms_-domestic and foreign, manufacturing and services.
} 
unobservable variation, differencing also removes fixed regional and industrial effects such as indicators of global engagement (e.g., tariffs), infrastructure, technological opportunity. One well-known cost of differencing is that it can aggravate measurement error in the regressors, and thereby introduce biases. In a multivariate setting, the direction of the bias cannot be signed. Longer time differences tend to attenuate this problem (Griliches and Hausman, 1986), so we report results for one-year, three-year, and five-year differences. Longer time differences may also be more appropriate if spillovers take time to materialize.

Second, in our differenced specifications we also include full sets of time, industry, and region fixed effects. These additional fixed effects control for unobservables that may be driving changes in key variables (e.g., we control not just for "Wales is an attractive region" but also for "the attraction of Wales is rising over time," or not just for "computers is a large industry" but also for "computers is a booming industry"). Thus, our findings rely not on differences in plant productivity and differences in foreign presence but on the deviation of differences in plant productivity and foreign presence from their year, region, and industry means.

If our differencing and fixed effects are sufficient, then in equation (1) the error term $\varepsilon$ is left uncontaminated by omitted variables. This will not be the case, however, if there are important unobservables that vary both across plants and over time. For example, managerial talent may not be fixed over time within plants. Without measures of these plant-and-time-varying factors, estimates from (1) may still be biased. Olley and Pakes (1996) show that these remaining unobservable shocks can be proxied from investment behavior, on the assumption that these shocks influence current investment but, since investment takes time, not current output. Olley and Pakes (1996) implement their method on telecommunication plants, as does Pavcnik (2000) on Chilean manufacturing plants.

As Griliches and Mairesse (1995) discuss, however, this structural approach depends on a number of assumptions: e.g., plants cannot undertake zero investment, other factors besides capital fully adjust to shocks each period, and markets are perfectly competitive. The sensitivity of this approach to violations of assumptions is an ongoing research question. For example, Levinsohn and Petrin (2000) propose using intermediate inputs rather than investment to address the underlying omitted-variables problem. For our purposes, we prefer not to assume perfect 
competition in light of the emphasis in the micro-spillovers literature on the competitive effects of foreign entrants. $\frac{17}{17}$

A third estimation issue is selection bias. Plants can choose to exit each period, but our data contains only the surviving plants. This might bias our estimates for foreign presence. Suppose that foreign presence truly does boost domestic-plant productivity, and thereby domestic-plant survival chances. In regions and/or industries with low foreign presence, we will observe only those plants whose unobservable offsetting benefits-e.g., good management-allow them to survive. But in regions and/or industries with high foreign presence, we are much more likely to observe all plants. This suggests that selection bias may understate the true relationship between inward FDI and productivity. Conversely, if firms with lower productivity growth are less likely to survive when foreign presence is high, selection may overestimate the relationship between inward FDI and productivity. Therefore, the direction of the overall potential bias is unknown.

Our use of differencing and the like does not control for selection; in fact, longer time differences may exacerbate it. To gauge the robustness of our results to this, we estimate some specifications adding to (2) a Heckman selection term, where the selection term is determined using a probit of exit on a number of variables including our foreign-presence measures and a polynomial in capital and investment. 18

A final estimation issue is weighting. Since we have the selected and non-selected data, we can construct sampling weights and run weighted regressions on the selected sample. However, there are at least two reasons why weighted regressions might be misleading. One is that the true marginal effects may differ across size groups. As DuMouchel and Duncan (1983) show, only in special cases do weighted regressions return an estimate of the average effect across groups. 19 A second issue is that if the sampling weights are measured with error, then weighted least squares

\footnotetext{
${ }^{17}$ Girma and Wakelin (2001) analyze productivity spillovers using both a specification similar to ours and the Olley-Pakes specification, and find that both approaches yield qualitatively identical results about spillovers.

${ }^{18}$ Our exclusion restrictions for the selection equation include, as in Olley and Pakes (1996), the assumption that the investment variables affect the entry/exit decision but not current output and thus productivity. We also have a potential selection bias since plants who have a downward employment shock are more likely to drop out of the ARD sample even though they have not truly died. If we were looking at employment this would mean that we would only see small plants with favourable characteristics, but since we are looking at productivity it is not clear how the selection bias would operate.

${ }^{19}$ DuMouchel and Duncan (1983) consider the following. Suppose one is trying to estimate a marginal effect $\beta$ between Y and set of variables $X$, where the data has been sampled and weights $w_{i}$ are assigned to the $i$ th observation. The OLS estimator of $\beta$ is $\beta_{\mathrm{OLS}}=\left(\mathrm{X}^{\prime} \mathrm{X}\right)^{-1} \mathrm{X}^{\prime} \mathrm{Y}$. The weighted least squares estimator is given by $\beta_{\mathrm{WLS}}=\left(\mathrm{X}^{\prime} \mathrm{WX}\right)^{-1} \mathrm{X}^{\prime} \mathrm{WY}$ where $\mathrm{W}$ is a diagonal matrix whose $i$ th diagonal element is $w_{i}$. Suppose, however, that the $\beta$ varies across size strata so that the model is $\mathrm{Y}=\mathrm{X} \beta(j)+\varepsilon$. A marginal effect of interest would be the weighted average marginal effect namely $\beta_{A V G}=\Sigma w_{i} \beta(j) / \Sigma w_{i}$ where the summation is over strata. DuMouchel and Duncan (1983) show that $\beta_{\mathrm{WLS}}$ is a biased estimate of $\beta_{\mathrm{AVG}}$ (unless all the regressors are constant), and so there is no reason to prefer weighting. In fact $\beta_{\mathrm{OLS}}$ is also biased, but there is no general result that one is less biased than another.
} 
can yield biased coefficient estimates. This is a real concern, both because the precise details of the sampling rules used by the ONS every year are no longer on record and because employment in the non-selected data from which weights can be approximated is in most cases imputed.

Because of concerns about these complications, our baseline estimates all use unweighted least squares. When using the non-selected sample in measuring foreign presence, however, for robustness we report results for weighted least squares as well, where the weights are constructed using employment bands by year, region, and industry. 20

\section{Summary}

In light of these various measurement and estimation issues, we estimate variations of this basic differenced equation.

$$
\begin{aligned}
\Delta \ln Y^{d}{ }_{i t}= & \alpha_{1} \Delta \ln K^{d}{ }_{i t}+\alpha_{2} \Delta \ln M^{d}{ }_{i t}+\alpha_{3} \Delta \ln S^{d}{ }_{i t}+\alpha_{4} \Delta \ln U^{d}{ }_{i t}+\alpha_{1} \Delta \ln h^{d}{ }_{i t}+ \\
& \sum_{k=0}^{T} \gamma_{1}^{k} \Delta \text { FOR }_{R, t-k}+\sum_{k=0}^{T} \gamma_{2}{ }^{k} \Delta F O R_{I, t-k}+ \\
& \delta_{1} \Delta \text { MSHARE }^{d}{ }_{i t-2}+\delta_{2} \Delta \operatorname{RENTS}^{d}{ }_{i t-2}+\delta_{3} \operatorname{RENTS~}_{i t-2}+\lambda_{t}+\lambda_{I}+\lambda_{R}+v_{i t}
\end{aligned}
$$

Equation (2) includes our variables for inputs, foreign presence, competition, and time, regional, and industry dummies $\left(\lambda_{t}, \lambda_{R}\right.$, and $\left.\lambda_{I}\right)$. We tried all the competition variables discussed above in both levels and changes, but only those shown in (2) were consistently significantly different from zero. We now turn to our estimation results.

\section{Estimation Results}

\section{Baseline Results}

Table 3 reports our baseline OLS estimates of equation (2) using short and long differences in combination with various lag structures. Each column reports a different difference length

\footnotetext{
20 The size bands are based on the following employment intervals: first less than 20; then eight intervals of 10 additional workers up to 100 (i.e., 20-29, 30-39, etc.); 100-199; 200-299; 300-399; and 400 or larger. The reason we include intervals for plants over 100 workers is that for various reporting reasons, some of these observations actually appear in the non-selected data. Although plants with less than 20 employees are not sampled, our data contain a few observations with less than 20 employees (this may be because large firms may choose to report by small local units). We dropped these observations in our weighted regressions because they would be given very large weights, which would exacerbate error in the weights.

${ }^{21}$ For a sub-sample of 20 four-digit SIC industries in the ARD, Harris and Robinson (2001) estimate productivity equations somewhat like equation (1). Their industries include cement and plaster; preparation of milk products, cocoa, etc; and steel wire. One important difference is their observations include plants in the non-selected sample, where the authors impute all unreported output and inputs data for these observations based on the non-selected employment information.
} 
and lag structure, with robust standard errors reported below coefficient estimates. Column 1 shows the simplest specification, namely, current $F O R_{R}$ and $F O R_{I}$ with one year differences. Both coefficient estimates are positive, consistent with positive productivity spillovers from foreign plants to domestic plants at both the regional and industry level, but the regional coefficient is insignificantly different from zero. The coefficient on $F O R_{I}$ suggests that a rise of 10 percentage points in $F O R_{I}$ for some industry, ceteris paribus, would raise output in each domestic plant in that industry by about $0.5 \%$. Because we control for inputs in estimating (2), this output increase is a TFP increase.

Since this magnitude is common to a number of the specifications we report below, it is worth trying to put it in some context. The observed rise in $F O R_{I}$ over the sample period 19731992 is about 11 percentage points. By our estimates of the previous paragraph, this implies that industry spillovers raised UK manufacturing industry TFP by about $0.5 \%$. Since actual TFP in U.K. manufacturing rose by about $10 \%$ over the estimation period, our estimates suggest that spillovers explain about 5\% of the observed 1973-1992 rise in U.K. manufacturing TFP. 22

Returning to Table 3, column 2 shows both foreign-presence measures dated $t-2$ and $t-3$, which are predetermined relative to the differenced dependent variable ${ }^{23}$ The second lag of $F O R_{I}$ is positive and the most significant. While both lags of $F O R_{R}$ are positive, neither is very significant. To see the magnitude of the overall effects across all lags, two lower rows also report the sum of the individual coefficients for the industry $\left(\Sigma F O R_{I}\right)$ and region $\left(\Sigma F O R_{R}\right)$. The P-value for the joint significance of the summed coefficients is reported in the next two rows, entitled $\mathrm{P}($ ind $)$ and $\mathrm{P}(\mathrm{reg})$. We see that the net industry effect is about the same magnitude as in column 1, and remains significant. The net regional effect is larger than in column 1, but remains insignificant.

Column 3 reports a specification using all lagged terms. Looking at the P-values, the regional effects are again jointly insignificant whereas the industrial effects are jointly significant. The net regional effect is now larger than in columns 1 and 2 . The net industrial effect is smaller, apparently because of a negative but insignificant (t-3) effect.

\footnotetext{
${ }^{22}$ To undertake this calculation, we needed to calculate total manufacturing TFP in a manner consistent with the regression from which we use the coefficients for $F O R_{I}$. We do this by subtracting from the change in log real output the weighted changes in the $\operatorname{logs}$ of K, M, S, U and $\mathrm{H}$ with the weights being the coefficients taken from estimates of (2).

${ }^{23}$ We also experimented with lags dated four years and beyond, but they were not significant.
} 
Columns 4 to 6 set out the three-year differences, and columns 7-9 the five-year differences. Comparing columns 4 and 7 with column 1, the results are similar: a significantly positive coefficient on $F O R_{I}$, with about the same magnitude as column 1, and an insignificant coefficient on $F O R_{R}$. Columns 5 and 8 , using the $(t-2)$ and $(t-3)$ lags, also give similar results, with a coefficient of around 0.05 for $F O R_{I}$. Finally, columns 6 and 9 both give jointly insignificant effects for $F O R_{R}$ and significant effects for $F O R_{I}$. It is also worth noting that the longer differences raise slightly the coefficients on $F O R_{I}$. This is consistent with the theory discussed earlier about measurement error and length of differences.

Taken together, the results in Table 3 suggest that industry-mediated productivity spillovers are positive and significant, with a semi-elasticity of 0.05 as our central estimate. Applied to actual data on foreign presence and TFP, this semi-elasticity suggests that spillovers explain about $5 \%$ of the actual rise in U.K. manufacturing TFP over our sample period. Our estimates of spillover effects along regional lines are less consistent. These estimates are generally positive, but are also mostly insignificantly different from zero.

These are our basic results. Tables 4 and 5 next show a set of extensions, first of splitting our data by groups of plants and second of decomposing foreign presence by country. Table 6 then shows a large number of robustness checks for various measurement and estimation issues.

\section{Extension: Spillovers by Absorptive Capacity}

It has been argued that the ability of domestic plants to realize FDI spillovers might depend on their absorptive capacity. Absorptive capacity may have something to do with the overall level of economic development in the host country. For example, in discussing their inability to find any FDI spillovers among Venezuelan plants, Aitken and Harrison (1999, p. 617) conjecture that "the economy [might] not [be] sufficiently developed or diversified, to receive large benefits from foreign presence." If there is indeed some minimum level of development countries need to realize spillovers, conditional on a country reaching that level there may also be variation in absorptive capacity among domestic plants due to differences in plant size, skill intensity, or technological sophistication. Perhaps only the "best practice" plants can take advantage of FDI spillovers. Conversely, perhaps best-practice plants, by definition, have already implemented foreign ideas and methods, such that spillovers accrue mainly to other plants with more to learn.

There is no obvious single measure of a plant's absorptive capacity. We proxy for it by splitting our sample into three groups based on their location in the distribution of three different 
performance measures: total employment, TFP, and skill intensity (i.e., non-production share of total employment). Consider the example of employment. Within each industry-year, we separated all plants into three groups based on their total plant employment: those below the $25^{\text {th }}$ percentile, those between the $25^{\text {th }}$ and $75^{\text {th }}$ percentile, and those above the $75^{\text {th }}$ percentile. Note that we separate by industry and by year, which accounts for cross-industry variation in total employment due to factors like underlying technology differences. We pool across all industryyears to obtain our three sub-samples, and then estimate (2) separately on each sub-sample. This process was repeated for our TFP and skill-intensity performance measures. The three different criteria seemed to generate broadly similar sub-samples, consistent with the micro evidence from several countries that best-practice plants appear as such along several dimensions. 24

Table 4 reports our estimation results for these various sub-samples, using the same specification as in column 1 of Table 3. There are two features of note. First, the results are consistent with Table 3 in that $F O R_{I}$ is generally positive and significant and $F O R_{R}$ insignificant. Second, there is a suggestion that spillovers are somewhat larger at lower points in the performance distribution. For all three performance measures, the coefficient on $F O R_{I}$ is insignificant and small for the best-practice plants above the $75^{\text {th }}$ percentile. For the lower two groups in the distribution, for all three performance measures the coefficient on $F O R_{I}$ is larger and is near or above standard significance levels. These differences we consider to be suggestive, as pairwise F-tests show the coefficients on $F O R_{I}$ to be significantly different (at the $10 \%$ level) in only two of the nine possible comparisons: within the skill-intensity distribution, between plants above the $75^{\text {th }}$ percentile and those between the $25^{\text {th }}$ and $75^{\text {th }}$ percentiles and between plants above the $75^{\text {th }}$ percentile and those below the $25^{\text {th }}$ percentile. Overall, we think Table 4 offers suggestive evidence consistent with the hypothesis that FDI spillovers accrue predominantly to plants further away from the best-practice frontier. 5

\footnotetext{
${ }^{24}$ Since employment in any year may be measured with error, in making the rankings we averaged employment in year $\mathrm{t}$ over years (t-1) and (t-2).

${ }^{25}$ One explanation of Table 4's patterns may be that the best-practice centiles contain most of the U.K.-headquartered multinationals. Recall that our ARD sample has no way to separate U.K.-owned plants between those that are part of U.K.headquartered multinationals and those that are part of purely domestic U.K. firms. If U.K. multinationals have little to learn from other multinationals, then this might help explain Table 4. Also, note that across the three different absorptive-capacity metrics in Table 4, each centile range does not contain the exact same number of plants because the extent of missing data varies across these metrics.
} 


\section{Extension: Spillovers by Nationality of Foreign Ownership}

Since the ARD reports the country of ownership of foreign plants, we can examine variation in spillovers with nationality. We are particularly interested in inward FDI from the world's other high-R\&D countries: the United States, France, Germany, and Japan.

Table 5 reports estimation results where $F O R_{R}$ and $F O R_{I}$ are constructed for each country separately. As with earlier tables, regional effects remain generally insignificant. For industry effects, our estimates are consistent with significantly positive spillovers from U.S. and French FDI, insignificant spillovers from German FDI, and significantly negative spillovers from Japanese FDI. The U.S. finding is consistent with both aggregate and micro-level evidence that the United States is at or near the world technology frontier. ${ }^{26}$ And the overall ranking of the four countries is strikingly consistent with Doms and Jensen (1998, Table 7.6). Looking at foreign affiliates in the United States, they find that relative to U.K. plants French plants have higher TFP, German plants have about the same TFP, and Japanese plants have lower TFP. 7 .

\section{Robustness Checks}

To verify the robustness of our main results we performed a large number of checks. Table 6 reports ten important checks, all using the column 1, Table 3 specification of contemporaneous foreign-presence measures and one-year time differences. It is important to note that many robustness checks were estimated for a wide range of specifications, but that we report just one specification for brevity. In many cases this one specification actually yields weaker results than others not reported; we will highlight some important instances.

The first five columns of Table 6 involve checks on measurement of our key foreign presence regressors, $F O R_{R}$ and $F O R_{I}$. Column 1 addresses what activity is used to calculate foreign presence. In Section 3 we argued that employment is our baselines measure of foreignaffiliate presence, but other options include capital stocks or employment by skill group. Column 1 reports estimation results measuring $F O R_{R}$ and $F O R_{I}$ using non-production employment. As before, industry effects are significant but region effects are not. Qualitatively

\footnotetext{
26 An example of country-level comparisons is Davis and Weinstein (2001). At the micro-level, Doms and Jensen (1998) document that parents of U.S. multinationals are more productive than U.S. affiliates of foreign-owned multinationals.

27 One interpretation of the large negative coefficient estimate for Japanese presence might be that Japanese firms exert particularly strong competitive pressures that our competition regressors do not fully capture. To test this idea we examined the industry distribution of Japanese FDI; over our sample period, about two-thirds of all Japanese employment in the U.K. was in electrical and electronic engineering. Excluding this industry from our measure of Japanese FDI presence reduced our coefficient estimate somewhat (to -0.183 ), but did not reduce it to zero.
} 
identical results were obtained using production employment or capital, all of which reflects the high sample correlations in levels and in differences among these different variables. 28

Columns 2 and 3 introduce the non-selected sample into the analysis. In column 2, we measure $F O R_{R}$ and $F O R_{I}$ using not just the selected sample but also the non-selected sample as well. Industry effects remain significant, with the slight decline in the coefficient estimate consistent with attenuation bias due measurement error in the imputed employment values in the non-selected sample. This slight decline generally disappears for alternative specifications with lagged regressors and/or longer time differences, so we regard the industry results to be entirely robust to this measurement issue. 29

In column 3 we again use the non-selected sample to measure foreign presence; we also use weighted rather than ordinary least squares as outlined in Section 3b. As in column 2, there is little evidence of spillovers along regional lines. The industry coefficient estimate is virtually unchanged from column 2, albeit now insignificant at standard levels. This decline in significance may reflect problems with measurement error in the sampling weights, discussed earlier. We note that this particular specification of WLS actually gives among the weakest evidence of industry spillovers. Weighted estimates from alternative specifications with lagged regressors and/or longer time differences-including those that omit the smallest plants, as discussed earlier — almost all yield larger, more significant industry coefficient estimates.

Our baseline measures of $F O R_{R}$ and $F O R_{I}$ are disaggregated between their numerators and denominators in column 4. This is to check that foreign presence matters in absolute levels as well as in shares. This appears to be the case. The coefficient estimate for total foreign employment by industry is significantly positive, while that for total foreign employment by region is basically zero. As discussed earlier (see Table 1), one reason to worry about differences between employment levels and shares might be the generally declining number of British plants over our sample period. To control for this directly, column 5 returns to using foreign-presence shares but adds regressors controlling both for the number of British plants by

\footnotetext{
${ }^{28}$ For example, the skilled-labor and unskilled-labor activity measures have sample correlations in levels and in differences (three-year and five-year) that range from 0.81 to 0.97 . Because of these very high correlations, multicollinearity problems inhibit attempts to enter both employment measures in the same regression to see if one employment group matters more.

${ }^{29}$ For example, the specification with contemporaneous regressors and five-year time differences yields a coefficient estimate on $F O R_{I}$ of 0.107 (t-statistic of 5.30) and on $F O R_{R}$ of -0.052 (t-statistic of 1.64).

${ }^{30}$ For example, the WLS specification with contemporaneous regressors and five-year time differences yields a coefficient estimate on $F O R_{I}$ of 0.087 (t-statistic of 3.08) and on $F O R_{R}$ of -0.091 (t-statistic of 0.98). For the analogous WLS specification that excludes all plants with fewer than 20 employees, the coefficient on $F O R_{I}$ is 0.110 (t-statistic of 4.45 ) and on $F O R_{R}$ is -0.017 (t-statistic of 0.46).
} 
industry and for the number by region (with both controls lagged one year). As column 5 shows, accounting for declines in total U.K. employment has no substantive impact on our estimates of the role of foreign presence by industry and region.

The second row of Table 6 addresses other measurement and estimation issues. Column 6 reports results from re-estimating the baseline model correcting for selection using a Heckman correction with the selection equation described earlier. Our estimates on the foreign-presence variables are qualitatively unchanged by performing this selection correction. That said, the Heckman diagnostic rho is -0.090 , with a standard error of 0.010 and an implied $\chi^{2}(1)$ test statistic of 84.60 , which indicates correlation between the error terms in the selection and productivity regressions and thus the potential for estimation bias if selection is ignored. We experimented with alternative specifications of the selection equation (e.g., dropping foreign presence or adding inventories); our results were qualitatively unchanged. We also re-estimated all nine specifications of Table 4 using different selection-correction specifications, as selection issues might be more important for particular sub-samples of our data. We obtained very similar selection-corrected coefficient estimates as those in Table 4, reinforcing its findings.

Column 7 reports results for a more-general specification of equation (2) in which we allow the various $\alpha$ coefficients on inputs to vary across all two-digit industries (by interacting input terms with industry dummies). One might worry that the assumption of equal $\alpha$ coefficients is not warranted, in a way that might bias our estimates for spillovers. This does not appear to be the case, however, as the coefficient estimates on $F O R_{R}$ and $F O R_{I}$ are very similar to the basic results in Table 3. Column 8 addresses a related specification issue; here, we modify our estimation equation by dropping the input regressors and replacing the regressand with TFP calculated from sample data on inputs, outputs, and cost shares. Again, estimates are consistent with positive spillovers from foreign industry presence but not regional presence.

The fact that some observations actually represent multi-plant establishments is addressed in column 9. Recall that this issue arises because firms are granted some latitude in completing ONS Census forms. To the extent that our data contain multi-plant establishments with constituent plants spanning multiple industries or regions, then our foreign-presence measures will contain some error relative to the ideal of fully separating out each plant. This measurement error might bias downward our baseline coefficient estimates; were this the case, our industry results would be a lower-bound estimate of spillover magnitudes, but our regional results thus far 
might be obscuring true regional spillovers. Column 9 estimates our baseline specification on the sub-sample of single-plant establishments. This group constitutes about two-thirds of our full sample, broadly consistent with Oulton's (1998) facts on this issue for the 1980s. For this subsample we continue to find estimates consistent with industry but not regional spillovers.

Finally, column 10 reports results for the sub-sample that excludes all plants located in Wales. As reported in Table 2a, Wales was one of the regions with the largest increase in foreign presence during our sample period, and we wanted to check that our main results were robust to excluding apparently important regions and/or industries. As demonstrated by the Wales exclusion, the results do seem robust in this way.

We also conducted other robustness checks that, for brevity, we do not report in Table 6. For example, as a further check on our industry estimates we excluded all observations that switched industry (at our baseline two-digit level) in either 1979 or 1980, the period of the large redefinition of industry classifications. One additional issue we mention is there may be serial correlation in the short-differenced residuals if there are short-run adjustments to shocks. Longdifferencing the data is one possible treatment for smoothing out short-run shocks. For our oneyear differences, we also added to equation (2) a lagged dependent variable and once-lagged input variables. We estimated this equation using the GMM method of Arellano and Bond (1991). The coefficient on $\triangle F O R_{I, t}$ was $0.054(\mathrm{t}=3.10)$ and on $\triangle F O R_{R, t}$ was $0.027(\mathrm{t}=1.15)$; the coefficient on the lagged dependent variable was $0.37(\mathrm{t}=7.47)$, which implies a long-run effect of $F O R_{I, t}$ of 0.085 . The $\mathrm{p}$ value for the test of no MA(1) error in the residuals was zero, rejecting the null of no autocorrelation, which is to be expected since first differencing should induce MA(1) residual autocorrelation. However, the $p$ value for the test of no $\operatorname{MA}(2)$ error in the residuals was 0.30 , which fails to reject the null of no autocorrelation. Thus, the test statistics indicate this dynamic specification is acceptable. In summary, we think our findings are robust to more complicated dynamic specifications. 3

\section{Public-Finance Implications: How Much Should Governments Pay To Attract FDI?}

In the introduction we reported estimated costs of government FDI subsidies for several high-profile cases in the United Kingdom and United States. Tables 3 through 6 report our

\footnotetext{
${ }^{31}$ We also ran the same specification with $\triangle F O R_{I, t-2,} \Delta F O R_{I, t-3}$ and $\triangle F O R_{R}$ t-2, and $\triangle F O R_{R, t-3}$. Just as Table 3, column 2, the coefficient on $\triangle F O R_{I, t-2}$ was significantly positive (coefficient $0.080, \mathrm{t}=4.15$ ) with the other variables insignificant (and with $\mathrm{p}$ values of zero and 0.16 for MA(1) and MA(2) autocorrelation, respectively).
} 
estimates of the spillover benefits to a host country from FDI. In this sub-section we attempt some calculations to compare these costs and benefits on a present-value, per-worker basis. We have in mind that subsidy costs are incurred at the start of a foreign plant's life (and perhaps thereafter as well), after which that plant delivers a flow of productivity-spillover benefits as long as it continues to operate. In performing the calculations, we reiterate the caveat that our estimation results are best interpreted as suggestive evidence consistent with productivity spillovers: we perform these calculations assuming that spillovers actually do exist.

The subsidy costs per worker can be easily calculated given reports of subsidy values and jobs covered. However, it is important to note the uncertainty surrounding both these quantities, as the reports are culled mainly from press reports without systematic verification of either values or jobs involved. For the four cases mentioned in the introduction, the costs per worker (all expressed in 2000 U.K. pounds) are Siemens (UK) £35,417; Motorola (UK) £14,356; Toyota (Kentucky, USA) £39,827; and Mercedes (Alabama, USA) $£ 117,178$. 32

The subsidy benefits per worker arise from the TFP boost enjoyed by the affected domestic plants thanks to the inward FDI. Because our estimates of productivity spillovers are for each year, they accumulate over the duration of foreign presence. This means we need to calculate the per year output boost for domestic plants per extra foreign job, and then discount these output boosts over the length of that job.

Consider a foreign plant coming into a particular industry $I$. If this new plant raises our foreign-presence measure $F O R_{I}$ by $\Delta \phi_{\text {}}$, then the percentage rise in output in each domestic plant in that industry is equal to $\left(\gamma_{1}\right)\left(\Delta \phi_{I}\right)$, where $\left(\gamma_{1}\right)$ is the spillover coefficient in equation (1). If the initial output across all domestic plants in that industry is given by $\mathrm{Y}_{\mathrm{IO}}{ }^{\mathrm{d}}$, then the level rise in domestic output in that industry, $\Delta \mathrm{Y}_{\mathrm{I}}^{\mathrm{d}}$, is given by $\Delta \mathrm{Y}_{\mathrm{I}}^{\mathrm{d}}=\left(\mathrm{Y}_{\mathrm{IO}}{ }^{\mathrm{d}}\right)\left(\gamma_{1}\right)\left(\Delta \phi_{\mathrm{I}}\right)$.

$\Delta \mathrm{Y}_{\mathrm{I}}^{\mathrm{d}}$ gives the rise in output per rise in the foreign-employment share, $\Delta \phi_{\mathrm{I}}$. To transform this into the rise per foreign worker, we need to calculate the relation between the rise in foreign employment share, $\Delta \phi_{\mathrm{I}}$, and the rise in foreign employment, $\Delta \mathrm{N}_{\mathrm{I}}{ }^{\mathrm{f}}$. This relation is given by

$$
\Delta \phi_{I}=\frac{\Delta N_{I}^{f}}{\left(N_{I 0}^{f}+N_{I 0}^{d}\right)} \frac{1}{\left(1+N_{I 0}^{f} / N_{I 0}^{d}+\Delta N^{f} / N_{I 0}^{d}\right)}
$$


where $N_{I O}{ }^{d}$ and $N_{I O}^{f}$ are the number of domestic and foreign jobs in the industry in the base period. The intuition behind this is as follows. Recall that $\phi_{I}=\left(\mathrm{N}_{\mathrm{IO}}{ }^{\mathrm{f}}\right) /\left(\mathrm{N}_{\mathrm{IO}}{ }^{\mathrm{d}}+\mathrm{N}_{\mathrm{IO}}{ }^{\mathrm{f}}\right)$. Thus, an increase in $N_{I O}{ }^{f}$ raises both the numerator and denominator of $\phi_{\mathrm{I}}$. This accounts for the two terms on the right-hand side of (3). The first term shows the direct effect on $\phi_{\mathrm{I}}$ from $\Delta \mathrm{N}_{\mathrm{I}}^{f}$ via the numerator of $\phi_{\mathrm{I}}$. The second terms shows the effect on $\phi_{\mathrm{I}}$ from $\Delta \mathrm{N}_{\mathrm{I}}{ }^{f}$ via the denominator of $\phi_{\mathrm{I}}$. The second term shows that the higher is foreign employment, the more is $\mathrm{N}_{I O}{ }^{\mathrm{f}} / \mathrm{N}_{I O}{ }^{\mathrm{d}}$ and so the less a given rise in $\mathrm{N}_{\mathrm{I}}{ }^{f}$ raises $\phi_{\mathrm{I}}$.

Combining (3) with the expression for $\Delta Y_{I}^{d}$, we can write the extra domestic output per foreign job, $\Delta Y_{I}{ }^{d} / \Delta N_{I}^{f}$, as follows:

$$
\frac{\Delta Y_{I}^{d}}{\Delta N_{I}^{f}}=\gamma_{1} Y_{I 0}{ }^{d} \frac{1}{\left(N_{I 0}^{f}+N_{I 0}^{d}\right)} \frac{1}{\left(1+N_{I 0}^{f} / N_{I 0}^{d}+\Delta N_{I}^{f} / N_{I 0}^{d}\right)}
$$

The extra domestic output per extra foreign job consists of four terms. The first, $\gamma_{1}$, is the estimated coefficient from equation (1) that gives the percentage change in domestic-plant output in response to a rise in foreign-employment share. The second term in (4), $\mathrm{Y}_{\mathrm{IO}}{ }^{\mathrm{d}}$, converts this percentage change into a level change. The third and fourth terms convert the rise in foreign employment share to rise in foreign employment in actual levels.

An expression similar to (4) would hold for productivity spillovers along regional lines, and we could therefore calculate the extra domestic output in region per foreign job created in a region. Our estimates of regional productivity spillovers were mostly small and insignificant, however, so we do not attempt any regional calculations. 33

Using data for the last year of our sample, 1992, we apply equation (4) to calculate the extra domestic output per foreign job. This quantity $\Delta Y_{I}^{d} / \Delta N_{I}^{f}$ varies by industry: we estimated $\gamma_{1}$ to be the same across industries, but each industry has different values of the other three components of the right-hand side of (4). Averaging our calculations across all industries, we

\footnotetext{
${ }^{32}$ We converted U.S. dollars to U.K. pounds using market exchange rates, and then converted all values into 2000 prices using the U.K. GDP deflator.

33 If spillovers truly operated along both industry and region lines, then a new foreign plant would necessarily stimulate spillovers along both lines. Our industry calculations ignore regional effects, consistent with the evidence in Tables 3 through 6 .
} 
obtain an average value of $\Delta Y_{I}{ }^{d} / \Delta N_{I}{ }^{f}$ of $£ 2,097$ in 1992 prices. This figure says that, ceteris paribus, each new foreign worker stimulates an extra $£ 2,097$ in output across all domestic plants in that worker's industry. This amount is about $£ 2,440$ at 2000 prices. 34

We can now compare our calculations of subsidy costs and benefits. To do this, we need to remember that the subsidy benefits accrue per year, and accordingly measure costs and benefits over the same time spans. For the two U.S. cases, note that we are assuming that our estimates of U.K. productivity spillovers apply in the same way to the United States. We have no way to evaluate this assumption, but maintain it simply for the sake of discussion.

The U.K. Siemens plant stayed open 18 months. At a discount rate of 5\%, $£ 2,440$ for 18 months is $£ 3,430$ : this is the value of spillover benefits per worker at this plant. The subsidy cost $£ 35,417$ per worker, an order of magnitude more than our best guess as to its spillover benefits. The U.K. Motorola plant survived 10 years. At a discount rate of 5\%, this translates into a present-value spillover benefits of $£ 18,841$ per worker. The subsidy cost $£ 14,356$ per worker, so in this case the government cost of the subsidy was about equal to its estimated productivity benefits.

The two U.S. cases are harder to judge, both because of the spillover caveat mentioned above and because the plants remain open today. The Toyota plant opened in 1988, and so thus far has generated a present-value spillover benefit of $£ 22,920$ per worker. The subsidy cost per worker is $£ 39,827$ in this case. This amount would be the present value of spillover benefits if the plant operates for 35 years, suggesting the Toyota plant must remain open 22 more years to "break even." The Mercedes plant opened in 1994, with an implied spillover benefit of $£ 14,119$ for its seven years of operation. This is an order of magnitude smaller than our calculated subsidy cost per worker of $£ 117,178$, which suggests that for this case the subsidy cost will exceed its productivity-spillover benefits.

A number of comments regarding these calculations are worth making. The first and most important is to reiterate that these calculations are only suggestive, as they rely on many assumptions and caveats. In particular, we have not considered benefits to foreign presence beyond the single issue of productivity spillovers. Foreign plants may bring benefits we have not

Alternatively, once could assume that industries and their owners are distributed evenly throughout regions, so that any new foreign plant would have a negligible impact on $F O R_{R}$.

34 As a benchmark, in 1992 gross output per domestic worker averaged about $£ 73,000$, with domestic wages averaging about $£ 15,000$. 
considered (e.g., civic benefits of "good citizen" employers). We also have not specified from where new foreign employees come. A new employee at a foreign plant may come from abroad, or from employment in a different domestic plant, or from unemployment. In the last case, the social value of the new foreign job may be higher.

A second comment is to stress the ceteris paribus nature of these calculations. For a foreign plant to continue generating spillovers over time, it needs to maintain its boost to the foreignaffiliate share of its industry employment. It is not length of plant life that is at issue, strictly speaking, but rather the length of increase in foreign-affiliate employment share. These calculations assume no other growth or decline in employment among all other plants. In reality, this may not be the case. For example, if over time spillovers stimulate hiring at domestic plants, then a foreign plant's boost to the foreign-affiliate employment share declines over time.

A final consideration is the incidence of subsidy costs and benefits. In the four cases we considered, host-country governments directly pay the subsidy costs. But these governments do not directly realize the subsidy benefits. Productivity spillovers accrue to domestic firms, not domestic governments. In principle, subsidies could be paid by coalitions of domestic firms that organize to pool contributions used as incentives to foreign firms. In practice, the standard collective-action problem of free riding may make such coalition-forming difficult.

Governments may be willing to pay subsidy costs based on the tax revenues they gain from the domestic-output boost. But if governments care only about their tax-revenue gain, then the cost they should be willing to incur equals just their share of the output bonus. In 1992 the maximum corporate tax rates were 33\% in the United Kingdom and 34\% in the United States. This means that spillover benefits accruing to governments are only about $1 / 3$ the total benefits calculated above, which makes the cost-benefit calculations even more unfavorable. Alternatively, governments might care about more than their tax-revenue gain, and thus may somehow internalize the spillover benefits enjoyed by domestic firms.

\section{Conclusions}

A large number of countries pay subsidies to attract FDI. One justification is that the social returns to FDI exceed the private returns, because of productivity spillovers from FDI to

\footnotetext{
${ }^{35}$ If part of the subsidy package governments offer is tax breaks, then the relevant effective tax rates are even lower. Courant (1994) surveys how to evaluate tax policy when used to foster economic development.
} 
domestic firms. In this paper we therefore examined two issues. First, are there productivity spillovers from FDI to domestic firms? Second, if there are such spillovers, what level of subsidies would be justified? Using a plant-level panel for U.K. manufacturing covering 19731992, we estimated production functions for domestic plants augmented with terms measuring foreign presence in the industry and region. Our major findings are as follows.

(a) We estimate a significantly positive correlation between a domestic plant's TFP and the foreign share of employment in that plant's industry. Typical estimates suggest that a 10 percentage-point increase in foreign presence in a U.K. industry raises the TFP of that industry's domestic plants by about 0.5 percent. This correlation is consistent with productivity spillovers from inward FDI to domestic plants. We do not find significant effects for foreign share of employment by region. Our estimates are robust across several issues regarding measurement and specification.

(b) These estimates suggest that the per-job value of spillovers appear to be less than perjob incentives governments have granted in recent high-profile cases, in some cases several times less.

We have also found some evidence that spillovers take time to permeate to domestic plants, that they are more important for plants at the lower end of the performance distribution, and that they are the largest from U.S.- and French-owned plants.

Ours is the first micro-level study we are aware of to find broad evidence of FDI spillovers. In future work there are at least two additional questions we plan to investigate. One important issue is the channels of productivity spillovers-e.g., access to suppliers, labor-market turnover. Another is whether different modes of FDI activity-greenfield investments, acquisitions of British firms, expansions of existing affiliates-have different impacts on domestic producers. 


\section{Data Appendix}

\section{Variable Definitions and Sources}

$\Delta \ln Y_{t} \quad$ The log change in total manufacturing real gross output (£s in 1980) (direct from ARD), deflated by 4 digit annual output price deflators supplied by the ONS.

$\Delta \ln K_{t} \quad$ The log change in total manufacturing real net capital stock (£s in 1980). Capital stock is estimated from establishment level investment in plant and machinery, vehicles and buildings, using perpetual inventory methods with the starting values and depreciation rates taken from O'Mahony and Oulton (1990) using the selected sample only. Depreciation rates: buildings $2.91 \%$, plant and machinery $11.097 \%$, and vehicles $28.1 \%$. Buildings and plant and machinery are deflated by two digit industry deflators, vehicles by annual deflators. Deflators were supplied, by Rachel Griffiths at IFS. In addition, establishments may disappear and appear from the ARD data due to sampling. This clearly creates problems for the perpetual inventory method. If we drop all establishments that disappear and reappear for at least one year we lose almost $50 \%$ of our selected sample. To fill in the missing year's investment data, we multiplied that year's industry investment by the establishment's average share of industry investment over the establishment's lifetime. After some experimentation we used this method to interpolate for establishments with at most three year's missing data. This means we only lose $10 \%$ of the sample. Although investment is of course volatile, establishments' investment shares by industry are in fact extremely stable and so we feel the induced inaccuracies are likely to be small relative to very large gain in sample size.

$\Delta \ln L_{t} \quad$ The log change in total manufacturing employment (direct from ARD).

$\Delta \ln S_{t} \quad$ The log change in total manufacturing non-manual employment (direct from ARD).

$\Delta \ln U_{t} \quad$ The log change in total manufacturing manual employment (direct from ARD).

$\Delta \ln M_{t} \quad$ The log change in total manufacturing real intermediate inputs (£s in 1980) (direct from ARD), deflated by four digit input price deflators supplied by the ONS.

$\triangle M S H A R E_{i t-2}$. The lagged change in market share, $(t-2)-(t-3)$. The market share is establishment nominal gross output as a share of four digit industry nominal gross output.

RENTS $_{i t-2}$. Rents lagged twice. It is defined as rents over net output, where rents are net output less material, capital and labour costs, expressed as a proportion of net output. Labour costs are the region- and four digit industry specific average manual and non-manual wage.

$\triangle R E N T S_{i t-2}$. The lagged change in rents, $(t-2)-(t-3)$.

$\triangle F O R_{I t} \quad$ The change in employment in a foreign-owned plant as a share of total employment in the industry. Industry is defined at the two-digit level, there are 22 two-digit industries.

$\triangle F O R_{R t} \quad$ The change in employment in a foreign-owned plant as a share of total employment in the region. There are 11 standard regions in the United Kingdom. 


\section{Appendix: Payments to Foreign Firms Operating in the United Kingdom}

The U.K. Government supports firms in many ways. 36 EU legislation restricts such support to special cases, such as investment that can be shown to be of social benefit in low-income areas designated by the EU as Assisted Areas. There are thus two main sources of support which are available in these areas. 37

1. EU money from the European Structural funds. This money is mostly paid out to large infrastructure projects.

2. Money from the U.K. government. These are discretionary grants made to support both small (i.e., less than $£ 500,000$ ) and large (i.e., above $£ 500,000$ ) private investment projects.

Most funding for foreign investment is for larger projects, and comes from Regional Selective Assistance (RSA). The projects must either create new employment or safeguard existing employment in the Assisted Areas. To be eligible for RSA, before investment goes ahead applicants have to disclose the investment size as well as its expected employment creation and duration. Foreign companies are eligible for RSA for greenfield investments as well as expansions or modernizations of existing operations. RSA is available for up to $15 \%$ of eligible project costs (mostly the costs of capital investment).

A government official judges whether an RSA-applied investment will create jobs and for how long. It is difficult to assess exactly how this judgement is made. An indication of the process involved is given by the following excerpt from the standard RSA application form; it states that all of the listed criteria must be met for the grant application to be considered.

\begin{tabular}{|l|}
\hline The project: \\
\hline Takes place in an Assisted Area. \\
Is aimed at more than a local market. \\
Is based on forecast growth in the market sector to ensure that displacement is not an issue. \\
Will involve a minimum capital expenditure of $£ 500,000$ on fixed assets. \\
Will directly create or safeguarded job in the business. \\
Expects the business as a whole to be financially viable and profitable within three years. \\
If the project is undertaken by a member of a group, the group will be financially stable. \\
Needs RSA as essential for the project to proceed.
\end{tabular}

\footnotetext{
${ }^{36}$ For more information see www.Invest-in-the-UK.com. General information about grants is at www.dti.gov.uk/support and www.invest.uk.com. See 〈http://news.bbc.co.uk/hi/english/business/the_company_file/newsid_332000/332560.stm> for information on the Siemens case and <http://news.bbc.co.uk/hi/english/uk/scotland/newsid_1294000/1294662.stm> for information on the Motorola case.

${ }^{37}$ Assisted Areas are designated as Tier 1, 2, or 3 depending on their deprivation level. U.K. examples of Tier 1, i.e., poorest, areas are the Sheffield and Liverpool areas.
} 


\section{References}

Aitken, Brian J., and Ann E. Harrison. 1999. "Do Domestic Firms Benefit from Foreign Direct Investment? Evidence from Venezuela." American Economic Review, June, pp. 605-618.

Arellano, Manuel, and Stephen Bond. 1991. "Some Tests of Specification for Panel Data: Monte Carlo Evidence and an Application to Employment Equations." Review of Economic Studies, Vol. 58 (2), April, pp. 277-297.

Baily, Martin Neil, and Robert M. Solow. 2001. "International Productivity Comparisons Built from the Firm Level.” Journal of Economic Perspectives, Vol. 15, No. 3, Summer, pp. 151-172.

Bartelsman, Eric J., and Doms, Mark. 2000. "Understanding Productivity: Lessons from Longitudinal Microdata." Journal of Economic Literature 38, September, pp. 569-594.

Black, Dan A. and William H. Hoyt. 1989. "Bidding for Firms." American Economic Review 79(5), pp. 1249-1256.

Blomstrom, Magnus. 1986. "Foreign Investment and Productive Efficiency: The Case of Mexico." Journal of Industrial Economics, 35 (1), pp. 97-110.

Branstetter, Lee. 2000. "Is Foreign Direct Investment a Channel of Knowledge Spillovers? Evidence from Japan's FDI in the United States.” NBER Working Paper \#8015, November.

Carr, David L., James R. Markusen, and Keith E. Maskus. 2001. "Estimating the Knowledge-Capital Model of the Multinational Enterprise." American Economic Review, 91(3), pp. 693-708.

Caves, Richard E. 1974. "Multinational Firms, Competition, and Productivity in Host-Country Industries." Economica, 41, pp. 176-193.

Chung, Wilbur, Will Mitchell, and Bernard Yeung. 1998. "Foreign Direct Investment and Host Country Productivity: The American Automotive Component Industry in the 1980s." Mimeo.

Courant, Paul N. 1994. "How Would You Know a Good Economic Development Policy if You Tripped Over One?" National Tax Journal 47, December, pp. 863-882.

Davis, Donald R., and David E. Weinstein. 2001. “An Account of Global Factor Trade." American Economic Review, forthcoming.

Disney, Richard, Jonathan E. Haskel, and Ylva Heden. 2000. "Exit, Entry and Establishment Survival in UK Manufacturing.” CEPR Discussion Paper DP2463, May.

Doms, Mark E., and J. Bradford Jensen. 1998. "Comparing Wages, Skills, and Productivity Between Domestically and Foreign-Owned Manufacturing Establishments in the United States." In Robert Baldwin, Robert Lipsey, and J. David Richardson (eds.), Geography and Ownership as Bases for Economic Accounting. Chicago: The University of Chicago Press, pp. 235-255.

Driffield, Nigel. 2000. "The Impact on Domestic Productivity of Inward Investment into the UK." Manchester School 69(1), pp. 103-119. 
DuMouchel, William H., and Greg J. Duncan. 1983. "Using Sample Survey Weights in Multiple Regression Analyses of Stratified Samples." Journal of the American Statistical Association, 78 (383), pp. 535-543.

Dunning, J. H. 1981. International Production and the Multinational Enterprise. London: George, Allen, and Unwin.

Girma, Sourafel and Katharine Wakelin. 2001. "Regional Underdevelopment: Is FDI the Solution? A Semiparametric Analysis.” Mimeo.

Griffith, Rachel. 1999. "Using the ARD Establishment Level Data to Look at Foreign Ownership and Productivity in the UK." Economic Journal, 109, June, pp. F416-F442.

Griliches, Zvi, and Jerry A. Hausman. 1986. "Errors in Variables in Panel Data." Journal of Econometrics, 31, pp. 93-118.

Griliches, Zvi, and Mairesse, J. 1995. "Production Functions: The Search for Identification." National Bureau of Economic Research Working Paper \#5067.

Haddad, M. and Ann E. Harrison. 1993. "Are there Positive Spillovers from Direct Foreign Investment?" Journal of Development Economics. 42, pp. 51-74.

Hanson, Gordon H. 2000. “Should Countries Promote Foreign Direct Investment?” G24 paper.

Harris, Richard. 2001. "Foreign Ownership and Productivity in the U.K.--Some Issues When Using the ARD Establishment Data." Scottish Journal of Political Economy, forthcoming.

Head, Keith. 1998. "Comment on Doms and Jensen." In Robert Baldwin, Robert Lipsey, and J. David Richardson (eds.), Geography and Ownership as Bases for Economic Accounting. Chicago: The University of Chicago Press, pp. 255-258.

Keller, Wolfgang. 2001. "The Geography and Channels of Diffusion at the World's Technology Frontier." National Bureau of Economic Research Working Paper No. 8150, March.

Krugman, Paul R. 1991 Geography and Trade. Cambridge: MIT Press.

Kugler, Maurice. 2001. “The Sectoral Diffusion of Spillovers from Foreign Direct Investment.”

Levinsohn, James and Amil Petrin. 2000. "Estimating Production Functions Using Inputs To Control For Unobservables.” National Bureau of Economic Research Working Paper \#7819.

Lipsey, Robert E., Magnus Blomstrom, and Eric Ramstetter. 1998. "Internationalized Production in World Output.” In Robert Baldwin, Robert Lipsey, and J. David Richardson (eds.), Geography and Ownership as Bases for Economic Accounting. Chicago: The University of Chicago Press, pp. 83-135.

Mansfield, Edwin and Anthony Romeo. 1980. "Technology Transfer to Overseas Subsidiaries by U.S.Based Firms." Quarterly Journal of Economics, 95 (4), pp. 737-750.

Marshall, Alfred. 1920. Principles of Economics, $8^{\text {th }}$ Edition. London: Macmillan. 
Moen, Jarle. 2000. "Is Mobility of Technical Personnel a Source of R\&D Spillovers?”, National Bureau of Economic Research Working Paper \#7834, August.

Motta, M., A. Fofur, and T. Ronde. 1999. "Foreign Direct Investment and Spillovers through Workers' Mobility.” CEPR Discussion Paper \#2194.

Nickell, Stephen. 1996. "Competition and Corporate Performance." Journal of Political Economy, 104, August, pp. 724-746.

Office of National Statistics. 1998. Economic Trends, Annual Supplement. London.

Olley, G. S. and Pakes, A. 1996. "The Dynamics of Productivity in the Telecommunications Equipment Industry.” Econometrica, 64 (6), pp. 1263-1297.

O’Mahony, Mary and Oulton, Nicholas. 1990. "Industry-Level Estimates of the Capital Stock in UK Manufacturing, 1948-85." NIESR Discussion paper, No 172, London.

Oulton, Nicholas. 1997. "The ABI Respondents Database: A New Resource for Industrial Economics Research.” Economic Trends, 528, November, pp. 46-57.

Oulton, Nicholas. 1998. "A Tale of Two Cycles: Closure, Downsizing, and Productivity Growth in UK Manufacturing, 1973-89.” NIESR Discussion Paper \#140.

Oulton, Nicholas. 2000. "Why Do Foreign-Owned Firms in the U.K. Have Higher Labour Productivity?" In N. Pain (ed), Inward Investment, Technological Change, and Growth: The Impact of Multinational Corporations on the U.K. Economy, New York: Palgrave.

PA Consultants. 1993. Regional Selective Assistance, 1985-88: An Evaluation. London: HMSO.

Pavcnik, Nina. 2000. "Trade Liberalization, Exit, and Productivity Improvements: Evidence From Chilean Plants.” National Bureau of Economic Research Working Paper \#7852, August.

Perry, John. 1985. "The Development of a New Register of Businesses.” Statistical News (70), August, pp. 70.13-70.16.

Rodriguez-Clare, Andres. 1996. "Multinationals, Linkages, and Economic Development." American Economic Review 86 (4), September, pp. 852-873.

Shaver, J. Myles, and Frederick Flyer. 2000. “Agglomeration Economies, Firm Heterogeneity, and FDI in the United States." Strategic Management Journal, 21 (12), pp. 1175-1193.

Song, J., Almeida P., and Wu, G. 2001. "Learning-by-Hiring: When is Mobility Useful?", paper presented at "Technological Innovation and Evolution" conference, March.

United Nations Conference on Trade and Development. 2000. World Investment Report: Cross-Border Mergers and Acquisitions and Development. New York: United Nations.

Vickers, John S. 1995. “Concepts of Competition.” Oxford Economic Papers 47, pp. 1-23. 
Table 1: Basic Facts of the ARD Panel

\begin{tabular}{ccccc}
\hline Year & \# Plants & \# British Plants & $\begin{array}{c}\text { \# Foreign } \\
\text { Plants }\end{array}$ & $\begin{array}{c}\text { \% Employment } \\
\text { in Foreign } \\
\text { Plants }\end{array}$ \\
& & & & $(4)$ \\
\hline 1973 & $21)$ & $(2)$ & $(3)$ & 0.12 \\
1974 & 23,413 & 20,418 & 995 & 0.13 \\
1975 & 21,798 & 22,333 & 1,153 & 0.13 \\
1976 & 21,820 & 20,665 & 1,133 & 0.14 \\
1977 & 21,860 & 20,363 & 1,238 & 0.16 \\
1978 & 18,823 & 17,426 & 1,497 & 0.15 \\
1979 & 17,965 & 16,441 & 1,597 & 0.16 \\
1980 & 14,901 & 13,432 & 1,469 & 0.17 \\
1981 & 14,717 & 13,155 & 1,562 & 0.18 \\
1982 & 14,468 & 12,920 & 1,548 & 0.18 \\
1983 & 14,046 & 12,493 & 1,553 & 0.17 \\
1984 & 18,352 & 16,793 & 1,559 & 0.17 \\
1985 & 13,783 & 12,416 & 1,367 & 0.17 \\
1986 & 13,192 & 11,927 & 1,265 & 0.16 \\
1987 & 13,316 & 12,026 & 1,290 & 0.16 \\
1988 & 13,460 & 12,161 & 1,299 & 0.16 \\
1989 & 18,982 & 17,370 & 1,612 & 0.18 \\
1990 & 14,036 & 12,544 & 1,492 & 0.20 \\
1991 & 13,926 & 12,319 & 1,607 & 0.22 \\
1992 & 13,449 & 11,826 & 1,623 & 0.23 \\
\hline
\end{tabular}

Note: In each year, a foreign-owned plant is defined as one in which a foreign business entity has at least a $20 \%$ ownership stake. All plants not meeting this criterion are defined as British owned. The employment shares in the final column report the share of overall U.K. manufacturing employment accounted for by foreign-owned plants. The sample of plants used for each year is the entire ARD selected sample, unweighted. See text for details on ownership and sampling issues. 


\section{Table 2a: Share of Foreign Employment, by Region}

\begin{tabular}{lcc}
\hline Region & 1977 & 1992 \\
\hline South East & 0.26 & 0.22 \\
East Anglia & 0.23 & 0.21 \\
South West & 0.12 & 0.14 \\
West Midlands & 0.08 & 0.17 \\
East Midlands & 0.08 & 0.11 \\
Yorkshire /Humberside & 0.11 & 0.13 \\
North West & 0.12 & 0.16 \\
North & 0.11 & 0.20 \\
Wales & 0.18 & 0.26 \\
Scotland & 0.19 & 0.23 \\
N. Ireland & 0.22 & 0.21 \\
\hline
\end{tabular}

Note: Each cell reports the share of that region-year's total manufacturing employment accounted for by foreign-owned plants. The sample of plants used for each year is the entire ARD selected sample, unweighted. See text for details on sampling issues.

\section{Table 2b: Share of Foreign Employment, by Industry}

\begin{tabular}{lcc}
\hline Two-digit industry & 1977 & 1992 \\
\hline 21 Extraction and preparation of metalliferous ores & 0.00 & 0.00 \\
22 Metal manufacturing & 0.05 & 0.16 \\
23 Extraction of minerals not elsewhere specified & 0.02 & 0.00 \\
24 Manufacture of non-metallic mineral products & 0.11 & 0.11 \\
25 Chemical industry & 0.29 & 0.34 \\
26 Production of man-made fibres & 0.16 & 0.19 \\
31 Manufacture of metal goods not elsewhere specified & 0.10 & 0.12 \\
32 Mechanical engineering & 0.18 & 0.19 \\
33 Manuf. of office machinery and data processing equipment & 0.41 & 0.58 \\
34 Electrical and electronic engineering & 0.22 & 0.26 \\
35 Manufacture of motor vehicles and parts thereof & 0.34 & 0.43 \\
36 Manufacture of other transport equipment & 0.02 & 0.10 \\
37 Instrumental engineering & 0.40 & 0.23 \\
41 Food and drink manufacturing industries ${ }^{1}$ & 0.12 & 0.08 \\
42 Food, drink and tobacco manufacturing industries ${ }^{2}$ & 0.11 & 0.23 \\
43 Textile industry & 0.04 & 0.07 \\
44 Manufacture of leather and leather goods & 0.04 & 0.00 \\
45 Footwear and clothing industries & 0.04 & 0.04 \\
46 Timber and wooden furniture industries & 0.03 & 0.03 \\
47 Manuf. of paper and paper products; printing and publishing & 0.16 & 0.15 \\
48 Processing of rubber and plastics & 0.23 & 0.21 \\
49 Other manufacturing industries & 0.14 & 0.07 \\
\hline
\end{tabular}

Note: Each cell reports the share of that industry-year's employment accounted for by foreignowned plants. The sample of plants used for each year is the entire ARD selected sample, unweighted. See text for details on sampling issues. Industries are by the U.K. Standard Industrial Classification.

1 - Oils, margarines, milk products; freezing, processing and preserving of meat, fish, fruit and vegetables; grain milling, bread and flour confectionery.

2 - Sugar and sugar confectionery, cocoa, coffee, tea, animal feeds and pet foods, and all others. 


\section{Table 3: The Effect of Foreign-Affiliate Presence on Productivity Baseline Specifications of Equation (2)}

\begin{tabular}{|c|c|c|c|c|c|c|c|c|c|}
\hline & \multicolumn{3}{|c|}{ 1-Year Differences } & \multicolumn{3}{|c|}{ 3-Year Differences } & \multicolumn{3}{|c|}{ 5-Year Differences } \\
\hline & (1) & (2) & (3) & (4) & (5) & (6) & (7) & (8) & (9) \\
\hline$\Delta \mathrm{FOR}_{\mathrm{I}, \mathrm{t}}$ & $\begin{array}{l}0.049 \\
(3.70)^{* *}\end{array}$ & & $\begin{array}{l}0.052 \\
(3.08)^{* *}\end{array}$ & $\begin{array}{l}0.053 \\
(3.16)^{* *}\end{array}$ & & $\begin{array}{l}0.086 \\
(3.58)^{* *}\end{array}$ & $\begin{array}{l}0.053 \\
(2.88) * *\end{array}$ & & $\begin{array}{l}0.022 \\
(0.85)\end{array}$ \\
\hline$\Delta \mathrm{FOR}_{\mathrm{I}, \mathrm{t}-1}$ & & & $\begin{array}{l}-0.060 \\
(3.42)^{* *}\end{array}$ & & & $\begin{array}{l}0.003 \\
(0.10)\end{array}$ & & & $\begin{array}{l}0.068 \\
(2.44)^{*}\end{array}$ \\
\hline$\Delta \mathrm{FOR}_{\mathrm{I}, \mathrm{t}-2}$ & & $\begin{array}{l}0.057 \\
(3.39)^{* *}\end{array}$ & $\begin{array}{l}0.043 \\
(2.31)^{*}\end{array}$ & & $\begin{array}{l}0.026 \\
(1.14)\end{array}$ & $\begin{array}{l}-0.005 \\
(0.17)\end{array}$ & & $\begin{array}{l}0.052 \\
(1.95)\end{array}$ & $\begin{array}{l}0.013 \\
(0.45)\end{array}$ \\
\hline$\Delta \mathrm{FOR}_{\mathrm{I}, \mathrm{t}-3}$ & & $\begin{array}{l}-0.006 \\
(0.39)\end{array}$ & $\begin{array}{l}-0.028 \\
(1.68)\end{array}$ & & $\begin{array}{l}0.030 \\
(1.33)\end{array}$ & $\begin{array}{l}0.079 \\
(3.01)^{* *}\end{array}$ & & $\begin{array}{l}0.011 \\
(0.40)\end{array}$ & $\begin{array}{l}0.010 \\
(0.37)\end{array}$ \\
\hline$\Delta \mathrm{FOR}_{\mathrm{R}, \mathrm{t}}$ & $\begin{array}{l}0.004 \\
(0.23)\end{array}$ & & $\begin{array}{l}0.015 \\
(0.71)\end{array}$ & $\begin{array}{l}-0.011 \\
(0.45)\end{array}$ & & $\begin{array}{l}0.044 \\
(1.25)\end{array}$ & $\begin{array}{l}-0.018 \\
(0.56)\end{array}$ & & $\begin{array}{l}-0.035 \\
(0.91)\end{array}$ \\
\hline$\Delta \mathrm{FOR}_{\mathrm{R}, \mathrm{t}-1}$ & & & $\begin{array}{l}0.006 \\
(0.25)\end{array}$ & & & $\begin{array}{l}0.002 \\
(0.05)\end{array}$ & & & $\begin{array}{l}-0.020 \\
(0.46)\end{array}$ \\
\hline$\Delta \mathrm{FOR}_{\mathrm{R}, \mathrm{t}-2}$ & & $\begin{array}{l}0.026 \\
(1.25)\end{array}$ & $\begin{array}{l}0.030 \\
(1.30)\end{array}$ & & $\begin{array}{l}-0.076 \\
(2.34)^{*}\end{array}$ & $\begin{array}{l}-0.089 \\
(2.35)^{*}\end{array}$ & & $\begin{array}{l}0.001 \\
(0.03)\end{array}$ & $\begin{array}{l}0.019 \\
(0.43)\end{array}$ \\
\hline$\Delta \mathrm{FOR}_{\mathrm{R}, \mathrm{t}-3}$ & & $\begin{array}{l}0.029 \\
(1.28)\end{array}$ & $\begin{array}{l}0.029 \\
(1.24)\end{array}$ & & $\begin{array}{l}0.075 \\
(2.28)^{*}\end{array}$ & $\begin{array}{l}0.103 \\
(2.71)^{* *}\end{array}$ & & $\begin{array}{l}0.036 \\
(0.82)\end{array}$ & $\begin{array}{l}0.034 \\
(0.77)\end{array}$ \\
\hline $\begin{array}{l}\Sigma \mathrm{FOR}_{\mathrm{I}} \\
\mathrm{P} \text { (ind) }\end{array}$ & 0.049 & $\begin{array}{l}0.051 \\
0.0009\end{array}$ & $\begin{array}{l}0.007 \\
0.0000\end{array}$ & 0.053 & $\begin{array}{l}0.056 \\
0.0491\end{array}$ & $\begin{array}{l}0.163 \\
0.0003\end{array}$ & 0.053 & $\begin{array}{l}0.063 \\
0.0467\end{array}$ & $\begin{array}{l}0.113 \\
0.0067\end{array}$ \\
\hline $\begin{array}{l}\Sigma \mathrm{FOR}_{\mathrm{R}} \\
\mathrm{P} \text { (reg) }\end{array}$ & 0.004 & $\begin{array}{l}0.055 \\
0.3026\end{array}$ & $\begin{array}{l}0.080 \\
0.5544\end{array}$ & -0.011 & $\begin{array}{l}-0.001 \\
0.0228\end{array}$ & $\begin{array}{l}0.060 \\
0.0452\end{array}$ & -0.018 & $\begin{array}{l}0.037 \\
0.6635\end{array}$ & $\begin{array}{l}-0.002 \\
0.6848\end{array}$ \\
\hline $\begin{array}{l}\text { Observations } \\
\text { R-squared }\end{array}$ & $\begin{array}{l}74,615 \\
0.56\end{array}$ & $\begin{array}{l}54,481 \\
0.58\end{array}$ & $\begin{array}{l}54,481 \\
0.58\end{array}$ & $\begin{array}{l}57,057 \\
0.70\end{array}$ & $\begin{array}{l}40,485 \\
0.71\end{array}$ & $\begin{array}{l}40,485 \\
0.71\end{array}$ & $\begin{array}{l}35,260 \\
0.76\end{array}$ & $\begin{array}{l}26,287 \\
0.76\end{array}$ & $\begin{array}{l}26,287 \\
0.76\end{array}$ \\
\hline
\end{tabular}




\section{Table 4: The Effect of Foreign-Affiliate Presence on Productivity Specifications of Equation (2) By Absorptive Capacity}

\begin{tabular}{|c|c|c|c|c|c|c|c|c|c|}
\hline \multirow[b]{2}{*}{ Centile Range } & \multicolumn{3}{|c|}{$\begin{array}{c}\text { Employment within } \\
\text { each two digit industry/year }\end{array}$} & \multicolumn{3}{|c|}{$\begin{array}{c}\text { TFP within } \\
\text { each two digit industry/year }\end{array}$} & \multicolumn{3}{|c|}{$\begin{array}{c}\text { Skill intensity within } \\
\text { each two digit industry/year }\end{array}$} \\
\hline & $\begin{array}{l}\text { Below } \\
25 \text { th }\end{array}$ & $\begin{array}{l}\text { Between } \\
25^{\text {th }} \& 75^{\text {th }}\end{array}$ & $\begin{array}{c}\text { Above } \\
75^{\text {th }}\end{array}$ & $\begin{array}{l}\text { Below } \\
25 \text { th }\end{array}$ & $\begin{array}{l}\text { Between } \\
25^{\text {th }} \& 75^{\text {th }}\end{array}$ & $\begin{array}{c}\text { Above } \\
75^{\text {th }}\end{array}$ & $\begin{array}{l}\text { Below } \\
25 \text { th }\end{array}$ & $\begin{array}{l}\text { Between } \\
25^{\text {th }} \& 75^{\text {th }}\end{array}$ & $\begin{array}{c}\text { Above } \\
75^{\text {th }}\end{array}$ \\
\hline$\Delta \mathrm{FOR}_{\mathrm{I}, \mathrm{t}}$ & $\begin{array}{l}0.074 \\
(1.75)\end{array}$ & $\begin{array}{c}0.053 \\
(3.08)^{* *}\end{array}$ & $\begin{array}{l}0.027 \\
(1.17)\end{array}$ & $\begin{array}{l}0.059 \\
(1.95)\end{array}$ & $\begin{array}{l}0.033 \\
(1.75)\end{array}$ & $\begin{array}{l}0.022 \\
(0.88)\end{array}$ & $\begin{array}{c}0.062 \\
(2.31)^{*}\end{array}$ & $\begin{array}{c}0.070 \\
(4.03) * *\end{array}$ & $\begin{array}{l}-0.009 \\
(0.29)\end{array}$ \\
\hline$\Delta \mathrm{FOR}_{\mathrm{R}, \mathrm{t}}$ & $\begin{array}{l}0.054 \\
(1.08)\end{array}$ & $\begin{array}{l}-0.014 \\
(0.60)\end{array}$ & $\begin{array}{l}0.000 \\
(0.01)\end{array}$ & $\begin{array}{l}0.004 \\
(0.12)\end{array}$ & $\begin{array}{l}0.033 \\
(1.38)\end{array}$ & $\begin{array}{l}-0.047 \\
(1.31)\end{array}$ & $\begin{array}{l}-0.008 \\
(0.24)\end{array}$ & $\begin{array}{l}0.000 \\
(0.00)\end{array}$ & $\begin{array}{l}0.033 \\
(0.89)\end{array}$ \\
\hline $\begin{array}{l}\text { Observations } \\
\text { R-squared }\end{array}$ & $\begin{array}{c}10,143 \\
0.51\end{array}$ & $\begin{array}{c}40,965 \\
0.58\end{array}$ & $\begin{array}{l}23,507 \\
0.57\end{array}$ & $\begin{array}{c}16,284 \\
0.60\end{array}$ & $\begin{array}{c}34,350 \\
0.60\end{array}$ & $\begin{array}{l}23,981 \\
0.51\end{array}$ & $\begin{array}{c}18,059 \\
0.56\end{array}$ & $\begin{array}{c}39,214 \\
0.58\end{array}$ & $\begin{array}{l}17,342 \\
0.54\end{array}$ \\
\hline $\begin{array}{l}\text { Note: Robust } \\
\text { average emplo } \\
\text { is the share of } \\
\text { output. Other }\end{array}$ & atistic & parenthes & * signi & at $5 \%$ & el; ** si & icant at & vel. $\mathrm{Th}$ & ercentiles & $\begin{array}{l}\text { se the } \\
\text { ensity } \\
\text { g real } \\
\text { tt and } \\
\text { etition }\end{array}$ \\
\hline
\end{tabular}

\section{Table 5: The Effect of Foreign-Affiliate Presence on Productivity Specifications of Equation (2) By Different Source Countries}

\begin{tabular}{|c|c|}
\hline \multicolumn{2}{|l|}{ United States } \\
\hline$\Delta \mathrm{FOR}_{\mathrm{I}, \mathrm{t}}$ & $\begin{array}{l}0.063 \\
(3.95)^{* * *}\end{array}$ \\
\hline$\Delta \mathrm{FOR}_{\mathrm{R}, \mathrm{t}}$ & $\begin{array}{l}-0.005 \\
(0.20)\end{array}$ \\
\hline France & \\
\hline$\Delta \mathrm{FOR}_{\mathrm{I}, \mathrm{t}}$ & $\begin{array}{l}0.106 \\
(2.43)^{*}\end{array}$ \\
\hline$\Delta \mathrm{FOR}_{\mathrm{R}, \mathrm{t}}$ & $\begin{array}{l}-0.055 \\
(0.86)\end{array}$ \\
\hline Germany & \\
\hline$\Delta \mathrm{FOR}_{\mathrm{I}, \mathrm{t}}$ & $\begin{array}{l}0.048 \\
(0.42)\end{array}$ \\
\hline$\Delta \mathrm{FOR}_{\mathrm{R}, \mathrm{t}}$ & $\begin{array}{l}-0.159 \\
(1.05)\end{array}$ \\
\hline Japan & \\
\hline$\Delta \mathrm{FOR}_{\mathrm{I}, \mathrm{t}}$ & $\begin{array}{l}-0.275 \\
(2.59)^{* * *}\end{array}$ \\
\hline$\Delta \mathrm{FOR}_{\mathrm{R}, \mathrm{t}}$ & $\begin{array}{l}-0.070 \\
(0.57)\end{array}$ \\
\hline Observations & 74,615 \\
\hline R-squared & 0.56 \\
\hline
\end{tabular}

Note: Robust t-statistics in parentheses. * significant at $5 \%$ level; ** significant at $1 \%$ level. The dependent variable is the difference of the log real output. Other regressors are the differenced logs of capital, materials, skilled employment, unskilled employment and hours as described in appendix, year dummies, 20 two-digit industry dummies, 10 region dummies and competition control variables. 


\section{Table 6: The Effect of Foreign-Affiliate Presence on Productivity Specifications of Equation (2) With Various Robustness Checks}

\begin{tabular}{|c|c|c|c|c|c|}
\hline $\begin{array}{l}\text { Robustness } \\
\text { Check }\end{array}$ & $\begin{array}{l}\text { Foreign Presence Uses } \\
\text { Skilled Employment } \\
\text { (1) }\end{array}$ & $\begin{array}{l}\text { Foreign Presence Uses } \\
\text { Non-Selected Sample } \\
\text { (2) }\end{array}$ & $\begin{array}{l}\text { Use Non-Selected } \\
\text { and Sampling Weights } \\
\text { (3) }\end{array}$ & $\begin{array}{l}\text { Foreign Presence Uses } \\
\text { Levels, Not Shares } \\
\text { (4) }\end{array}$ & $\begin{array}{l}\text { Control for Number of } \\
\text { U.K.-Owned Plants } \\
\text { (5) }\end{array}$ \\
\hline$\Delta \mathrm{FOR}_{\mathrm{I}, \mathrm{t}}$ & $\begin{array}{l}0.048 \\
(3.80) * *\end{array}$ & $\begin{array}{l}0.038 \\
(2.63)^{* *}\end{array}$ & $\begin{array}{l}0.039 \\
(1.16)\end{array}$ & $\begin{array}{l}2.47 \times \text { E-7 } \\
(4.62)^{* *}\end{array}$ & $\begin{array}{l}0.051 \\
(3.84)^{* *}\end{array}$ \\
\hline$\Delta \mathrm{FOR}_{\mathrm{R}, \mathrm{t}}$ & $\begin{array}{l}-0.010 \\
(0.65)\end{array}$ & $\begin{array}{l}0.001 \\
(0.08)\end{array}$ & $\begin{array}{l}-0.057 \\
(1.03)\end{array}$ & $\begin{array}{l}-6.89 \times \text { E-9 } \\
(0.18)\end{array}$ & $\begin{array}{l}0.002 \\
(0.11)\end{array}$ \\
\hline $\begin{array}{l}\text { Observations } \\
\text { R-squared }\end{array}$ & $\begin{array}{l}74,615 \\
0.56 \\
\end{array}$ & $\begin{array}{l}74,615 \\
0.56 \\
\end{array}$ & $\begin{array}{l}74,615 \\
0.53 \\
\end{array}$ & $\begin{array}{l}74,615 \\
0.56 \\
\end{array}$ & $\begin{array}{l}74,615 \\
0.56 \\
\end{array}$ \\
\hline $\begin{array}{l}\text { Robustness } \\
\text { Check }\end{array}$ & $\begin{array}{l}\text { Perform Heckman } \\
\text { Selection Correction } \\
\text { (6) }\end{array}$ & $\begin{array}{l}\text { Vary by Each Sector } \\
\text { All Input Coefficients } \\
\text { (7) }\end{array}$ & $\begin{array}{l}\text { Use Constructed TFP } \\
\text { as Regressand } \\
\text { (8) }\end{array}$ & $\begin{array}{l}\text { Exclude Observations } \\
\text { with Multiple Plants } \\
\text { (9) }\end{array}$ & $\begin{array}{l}\text { Exclude Observations } \\
\text { in Wales } \\
(10)\end{array}$ \\
\hline$\Delta \mathrm{FOR}_{\mathrm{I}, \mathrm{t}}$ & $\begin{array}{l}0.051 \\
(3.84)^{* *}\end{array}$ & $\begin{array}{l}0.048 \\
(3.65)^{* *}\end{array}$ & $\begin{array}{l}0.029 \\
(2.08)^{*}\end{array}$ & $\begin{array}{l}0.044 \\
(2.73)^{* *}\end{array}$ & $\begin{array}{l}0.050 \\
(3.68)^{* *}\end{array}$ \\
\hline$\Delta \mathrm{FOR}_{\mathrm{R}, \mathrm{t}}$ & $\begin{array}{l}-0.001 \\
(0.07)\end{array}$ & $\begin{array}{l}0.004 \\
(0.24)\end{array}$ & $\begin{array}{l}0.002 \\
(0.14)\end{array}$ & $\begin{array}{l}-0.011 \\
(0.54)\end{array}$ & $\begin{array}{l}0.004 \\
(0.21)\end{array}$ \\
\hline $\begin{array}{l}\text { Observations } \\
\text { R-squared }\end{array}$ & $\begin{array}{l}74,615 \\
-\end{array}$ & $\begin{array}{l}74,615 \\
0.57\end{array}$ & $\begin{array}{l}75,157 \\
0.03\end{array}$ & $\begin{array}{l}48,787 \\
0.56\end{array}$ & $\begin{array}{l}71,985 \\
0.56\end{array}$ \\
\hline
\end{tabular}

Note: Robust t-statistics in parentheses. * significant at $5 \%$ level; ** significant at $1 \%$ level. All regressions shown here use one-year time differences, analogous to column 1 of Table 3. The dependent variable is the difference of the log real output. Other regressors are the differenced logs of capital, materials, skilled employment, unskilled employment and hours as described in appendix, year dummies, 20 two-digit industry dummies, 10 region dummies and competition control variables. For brevity, these coefficient estimates are not reported. Column 1 measures foreign activity using skilled employment rather than total employment. Column 2 measures foreign presence accounting for employment estimates from the non-selected sample. Column 3 does the same, but also weights observations using sampling weights. Column 4 adds as control regressors the lagged number of U.K.-owned plants by industry and region. Column 5 measures foreign presence using the absolute number of foreign employees, rather than employment shares. Column 6 presents results corrected for sample selection; the Heckman selection equation regressors include the foreign-presence variables, a fourth-degree polynomial for log real investment, and a fourth degree polynomial for log real capital. The number of observations reported is the uncensored count; there are 108,700 observations total. The Heckman diagnostic rho is -0.090 , with a standard error of 0.010 and an implied $\chi^{2}$ (1) test statistic of 84.60. Column 7 estimates a separate set of the five input coefficients for each two-digit industry. Column 8 uses as the regressand TFP calculated by the standard method that assumes perfect competition, and thus omits the input regressors. Column 9 excludes all observations that cover multiple plant locations. Column 10 excludes all observations located in Wales. For all these robustness checks, see text for details. 